\title{
Inner Ear Connexin Channels: Roles in Development and Maintenance of Cochlear Function
}

\author{
Fabio Mammano ${ }^{1,2,3}$ \\ ${ }^{1}$ University of Padova, Department of Physics and Astronomy "G. Galilei," Padova 35129, Italy \\ ${ }^{2} \mathrm{CNR}$ Institute of Cell Biology and Neurobiology, Monterotondo 00015, Italy \\ ${ }^{3}$ Shanghai Institute for Advanced Immunochemical Studies, ShanghaiTech University, Shanghai 201210, China \\ Correspondence: fabio.mammano@unipd.it
}

Connexin 26 and connexin 30 are the prevailing isoforms in the epithelial and connective tissue gap junction systems of the developing and mature cochlea. The most frequently encountered variants of the genes that encode these connexins, which are transcriptionally coregulated, determine complete loss of protein function and are the predominant cause of prelingual hereditary deafness. Reducing connexin 26 expression by Cre/loxP recombination in the inner ear of adult mice results in a decreased endocochlear potential, increased hearing thresholds, and loss of $>90 \%$ of outer hair cells, indicating that this connexin is essential for maintenance of cochlear function. In the developing cochlea, connexins are necessary for intercellular calcium signaling activity. Ribbon synapses and basolateral membrane currents fail to mature in inner hair cells of mice that are born with reduced connexin expression, even though hair cells do not express any connexin. In contrast, pannexin 1, an alternative mediator of intercellular signaling, is dispensable for hearing acquisition and auditory function.

In the sixties and seventies of the past century, gap junctions (GJs) were identified as planar arrays of intercellular conduits formed by the head-to-head docking, in the extracellular space, of two so-called connexons (Dewey and Barr 1962; Robertson 1963; Revel and Karnovsky 1967; Brightman and Reese 1969; Caspar et al. 1977; Makowski et al. 1977). Each connexon is a hexameric complex formed by circumferentially arranged connexin $(\mathrm{Cx})$ protein subunits (Goodenough 1974), which delineate a pore in the plasma membrane. Thus, the coaxial arrangement of two docked connexons establishes a communication pathway between the cytoplasm of the two adjoined cells (Fig. 1A,B).

Twenty connexin genes are expressed both in humans (identified by a " $G J$ ” prefix) and in mice (identified by a "Gj" prefix) (Table 1). Note that two connexins are human only (CX25, CX59), and two are mouse only (Cx33, Cx23). All connexins are thought to share the same topology, with cytoplasmic amino and carboxyl termini, four transmembrane domains connected by two extracellular loops and a cytoplasmic loop (Beyer and Berthoud 2018). The amino acids forming these domains in CX26 are listed in Table 2.

Editors: Guy P. Richardson and Christine Petit

Additional Perspectives on Function and Dysfunction of the Cochlea available at www.perspectivesinmedicine.org

Copyright (C) 2019 Cold Spring Harbor Laboratory Press; all rights reserved; doi: 10.1101/cshperspect.a033233

Cite this article as Cold Spring Harb Perspect Med 2019;9:a033233 

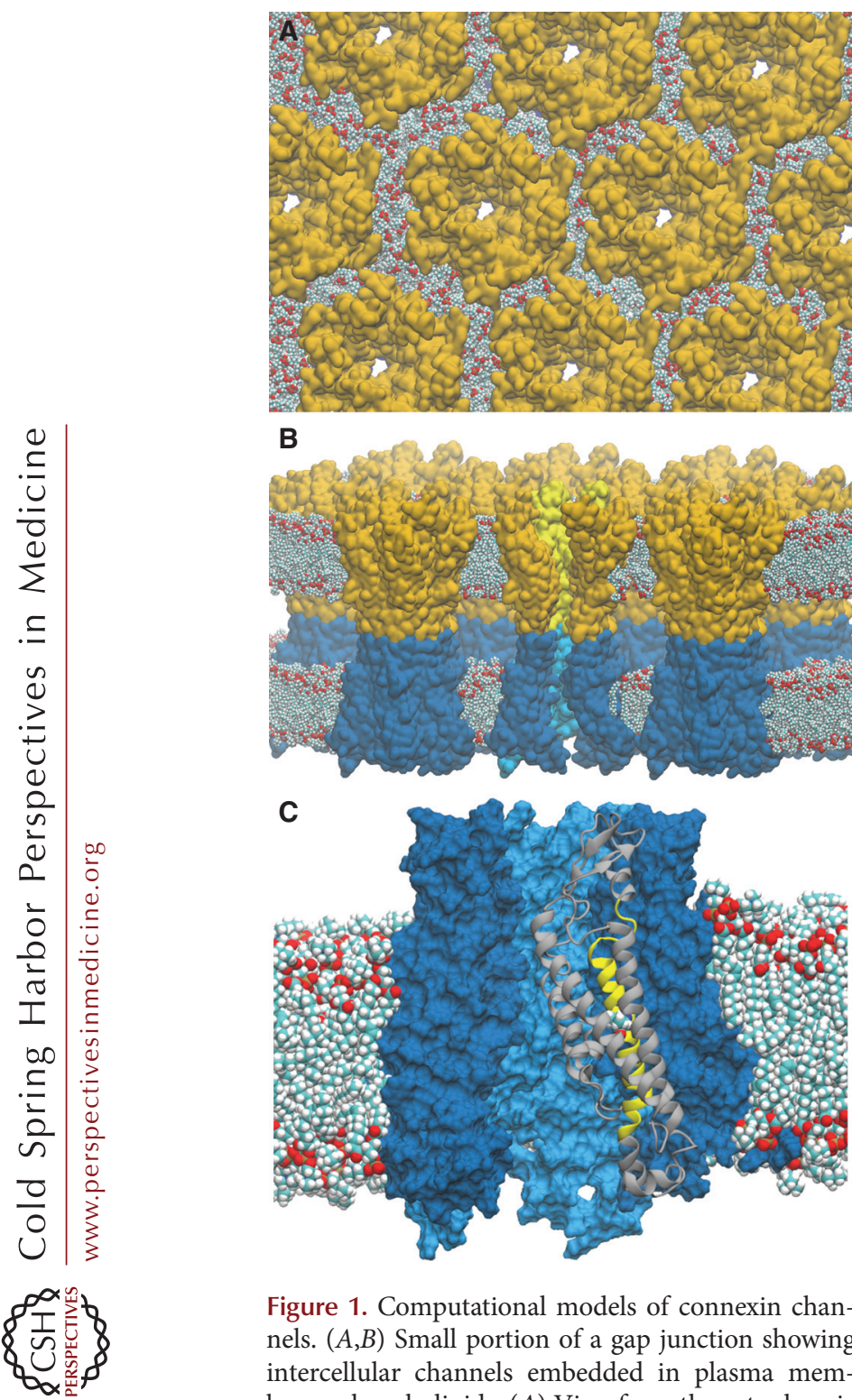

Figure 1. Computational models of connexin channels. $(A, B)$ Small portion of a gap junction showing intercellular channels embedded in plasma membrane phospholipids. $(A)$ View from the cytoplasmic side of one of the two adjacent membranes. (B) Transverse section in a plane orthogonal to the plasma membranes; four of the 12 protomers have been removed from the channel in the center to show its pore. (C) Model of a Cx26 hemichannel: one of the six protomers has been removed to show the channel pore (light blue); four connexins are rendered as solid surface and the remaining connexin is represented as a cartoon to highlight its 3D structure; transmembrane helix 2 (TM2) is colored in yellow. The computational and rendering methods used to generate this figure are described in Zonta et al. $(2012,2014)$ and Xu et al. (2017).
Connexins are posttranslationally oligomerized to form connexons before membrane insertion either within the endoplasmic reticulum (ER) or in the trans-Golgi network (Thomas et al. 2005; Aasen et al. 2018). Connexons can be homomeric (composed of six identical connexin protomers) or heteromeric (formed by two or more different connexin isoforms). Therefore, docked connexons can form (1) homomeric-homotypic, (2) heteromeric-homotypic, (3) homomeric-heterotypic, or (4) heteromeric-heterotypic GJ channels (Kumar and Gilula 1996). Thousands of GJ channels aggregate in a plaque (Solan and Lampe 2018) at an estimated density of 12.500 channels $/ \mu \mathrm{m}^{2}$ (Forge et al. 2003a) driven by protein-protein interaction forces (Abney et al. 1987). In plaques purified from a HeLa cell line overexpressing Cx26, atomic force microscopy imaging revealed GJ channels assembled in a regular hexagonal lattice with a unit cell distance of $7.7 \pm$ $0.5 \mathrm{~nm}$ (Muller et al. 2002).

Clustering in GJ plaques is considered a prerequisite for the opening of $\mathrm{GJ}$ channels (Bukauskas et al. 2000). Based on the available crystallographic data at $3.5 \AA$ resolution, it has been estimated that the pore of the open CX26 GJ channel achieves a minimum diameter of $\sim 14 \AA$ (Maeda et al. 2009; Zonta et al. 2012, 2013). Size exclusion studies, using permeant molecules of various size, suggest that GJ channels formed by other connexin isoforms are characterized by similarly large pores, and consequently that GJs allow adjacent cells to exchange cytoplasmic molecules with a cut-off molecular mass up to $\sim 1.4 \mathrm{kDa}$ (Leybaert et al. 2017), a size that includes all small inorganic ions with their hydration shells (Volkov et al. 1997). The list of permeating molecules could potentially comprise $>35,000$ members of the Human Metabolome Database $^{4}$ (Esseltine and Laird 2016). Permeability studies for glucose, ADP, ATP, adenosine, glutamate, and glutathione (Goldberg et al. 1999, 2002), secondary messengers (Niessen et al. 2000; Beltramello et al. 2005; Bedner et al. 2006; Hernandez et al. 2007; Kanaporis

${ }^{4}$ http://www.hmdb.ca/structures/search/metabolites/mass. 
Inner Ear Connexin Channels

Table 1. List of human and mouse connexin genes

\begin{tabular}{|c|c|c|c|c|c|}
\hline \multicolumn{3}{|c|}{ Human } & \multicolumn{3}{|c|}{ Mouse } \\
\hline OMIM ID & Gene symbol & Protein name & Protein name & Gene symbol & MGI ID \\
\hline 121014 & GJA1 & CX43 & $\mathrm{Cx} 43$ & Gja1 & 95713 \\
\hline 121015 & GJA3 & CX46 & $\mathrm{Cx} 46$ & Gja3 & 95714 \\
\hline 121012 & GJA4 & CX37 & $\mathrm{Cx} 37$ & Gja4 & 95715 \\
\hline 121013 & GJA5 & CX40 & $\mathrm{Cx} 40$ & Gja5 & 95716 \\
\hline- & - & - & $\mathrm{Cx} 33$ & Gja6 & 95717 \\
\hline 600897 & GJA8 & CX50 & Cx50 & Gja8 & 99953 \\
\hline 611923 & GJA9 & CX59 & - & - & - \\
\hline 611924 & GJA10 & CX62 & Cx57 & Gjalo & 1339969 \\
\hline 304040 & GJB1 & CX32 & $\mathrm{Cx} 32$ & Gjbl & 95719 \\
\hline 121011 & GJB2 & CX26 & $\mathrm{Cx} 26$ & Gjb2 & 95720 \\
\hline 603324 & GJB3 & CX31 & $\mathrm{Cx} 31$ & Gjb3 & 95721 \\
\hline 605425 & GJB4 & CX30.3 & Cx30.3 & Gjb4 & 95722 \\
\hline 604493 & GJB5 & CX31.1 & Cx31.1 & Gjb5 & 95723 \\
\hline 604418 & GJB6 & CX30 & $\mathrm{Cx} 30$ & Gjb6 & 107588 \\
\hline 611921 & GJB7 & CX25 & - & - & \\
\hline 608655 & GJC1 & CX45 & $\mathrm{Cx} 45$ & Gjc1 & 95718 \\
\hline 608803 & GJC2 & CX47 & $\mathrm{Cx} 47$ & Gjc2 & 2153060 \\
\hline 611925 & GJC3 & CX30.2/31.3 & $\mathrm{Cx} 29$ & Gjc3 & 2153041 \\
\hline 607058 & GJD2 & CX36 & Cx36 & Gjd2 & 1334209 \\
\hline 607425 & GJD3 & CX31.9 & $\mathrm{Cx} 30.2$ & Gjd3 & 2384150 \\
\hline 611922 & GJD4 & CX40.1 & Cx39 & Gjd4 & 2444990 \\
\hline- & - & - & $\mathrm{Cx} 23$ & Gje1 & 1923993 \\
\hline
\end{tabular}

et al. 2008; Carrer et al. 2018), short interfering RNA (siRNA), and microRNA (miRNA) (Valiunas et al. 2005; Zong et al. 2016) yielded up to 33 -fold differences in the estimated unitary permeability of different channels for different molecules.

Table 2. Cx26 structural domains and corresponding amino acid positions

\begin{tabular}{lll}
\hline $\begin{array}{l}\text { Amino } \\
\text { acid }\end{array}$ & \multicolumn{1}{c}{ Domain } & Acronym \\
\hline $1-20$ & $\begin{array}{c}\text { Amino terminus, } \\
\text { cytoplasmic } \\
\text { Transmembrane helix 1 }\end{array}$ & NT \\
21-40 & TM1 \\
$41-75$ & Extracellular loop 1 & ECL1 \\
$76-98$ & Transmembrane helix 2 & TM2 \\
99-131 & Cytoplasmic loop & CL \\
$132-154$ & Transmembrane helix 3 & TM3 \\
$155-192$ & Extracellular loop 2 & ECL2 \\
$193-215$ & Transmembrane helix 4 & TM4 \\
$216-226$ & Carboxyl terminus, & CT \\
& cytoplasmic & \\
\hline
\end{tabular}

Of note, undocked connexons can establish a communication pathway between cell cytoplasm and the extracellular milieu by operating as regular plasma membrane channels, referred to as connexin hemichannels (Fig. 1C) (Li et al. 1996). Open hemichannels lack ion selectivity and mediate autocrine/paracrine signaling by the release or uptake of small molecules including ATP (Leybaert et al. 2003), glutamate (Ye et al. 2003), lactate (Karagiannis et al. 2016), oxidized nicotinamide adenine dinucleotide (Bruzzone et al. 2001), prostaglandin $\mathrm{E}_{2}$ (Cherian et al. 2005), reduced glutathione (Rana and Dringen 2007; Tong et al. 2015), which are critical for cell-cell communication (Wang et al. 2013; Saez and Leybaert 2014) and the regulation of inflammatory responses (Willebrords et al. 2016).

Permeation is regulated by numerous factors that control the opening and closing (i.e., gating) of GJ channels and connexin hemichannels, including voltage (Barrio et al. 1991; Verselis et al. 1994, 2000; Saez et al. 2005; Paulauskas et al. 
F. Mammano

2012; Snipas et al. 2017), pH (Peracchia et al. 2000b; Palacios-Prado et al. 2009; Sanchez et al. 2014), redox potential (Retamal et al. 2007; Retamal 2014), $\mathrm{CO}_{2}$ (Huckstepp et al. 2010; Meigh et al. 2013), nitric oxide, and $S$ nitrosylation (Retamal et al. 2006, 2009), phosphorylation (Kim et al. 1999; Moreno 2005), and other posttranslational modifications (D'Hondt et al. 2013; Aasen et al. 2018). Connexin hemichannels remain predominantly closed at negative membrane potential and/or in the presence of millimolar levels of extracellular divalent cations $\left(\mathrm{Ca}^{2+}\right.$ and $\mathrm{Mg}^{2+}$ ) (Li et al. 1996; Pfahnl and Dahl 1999; Kamermans et al. 2001; Gomez-Hernandez et al. 2003; Verselis and Srinivas 2008; Bennett et al. 2016). Atomic force microscopy revealed that the pore at the extracellular mouth of Cx26 hemichannels changed diameter from $13 \pm 3 \AA$, in the absence of $\mathrm{Ca}^{2+}$, to $5 \pm 3 \AA$ in $0.5 \mathrm{~mm} \mathrm{Ca}^{2+}$ (Muller et al. 2002). A similar effect on pore size was imaged by atomic force microscopy in Cx43 hemichannels (Thimm et al. 2005).

GJ channels tend to close in response to an increase of the cytosolic free calcium concentration $\left(\left[\mathrm{Ca}^{2+}\right]_{\mathrm{c}}\right)$ in a variable range, from $300 \mathrm{~nm}$ to several $\mu \mathrm{M}$, depending on the connexin isoforms (Rose and Loewenstein 1975; Peracchia 2004; Lurtz and Louis 2007). The $\mathrm{Ca}^{2+}$-dependent inhibition of different GJ channels might share a common mechanism mediated by calmodulin (Peracchia et al. 1983, 2000a; Zhou et al. 2009). In contrast, connexin hemichannels show a more complicated, bell-shaped dependence of their open probability $\left(P_{\mathrm{o}}\right)$ on $\left[\mathrm{Ca}^{2+}\right]_{\mathrm{c}}$, as the $P_{\mathrm{o}}$ increases for $\left[\mathrm{Ca}^{2+}\right]_{\mathrm{c}} \leq 500 \mathrm{~nm}$ and decays if $\left[\mathrm{Ca}^{2+}\right]_{\mathrm{c}}$ increases further (De Vuyst et al. 2006, 2009; Carrer et al. 2018). A pivotal role for calmodulin has been proposed also for this incompletely characterized gating phenomenon (Zhang et al. 2006; Hu et al. 2018).

\section{CELL COUPLING IN THE MAMMALIAN COCHLEA}

Intercellular junctions in the mammalian cochlea were initially characterized by electrophysiology (Santos-Sacchi and Dallos 1983; Oesterle and Dallos 1990; Santos-Sacchi 1991; Mam- mano et al. 1996) and electron microscopy studies (Jahnke 1975; Reale et al. 1975; Gulley and Reese 1976; Iurato et al. 1976a,b; Hama and Saito 1977; Franke 1978, 1979; Nadol 1978; Forge 1984; Bagger-Sjoback et al. 1987; Carlisle et al. 1990; Sakagami et al. 1993), leading to the identification of two distinct cellular networks, referred to as the epithelial GJ system (E-sys) and the connective tissue GJ system (C-sys), respectively (Kikuchi et al. 1995). In rodents, the E-sys forms around embryonic day 16, and encompasses supporting cells of the organ of Corti, the bordering epithelial cells of the inner sulcus and outer sulcus, the interdental cells of the spiral limbus and the root cells (Kikuchi et al. 1995) that extend their process into the spiral ligament (Jagger and Forge 2013). By postnatal (P) day 5 (P5, where P0 is date of birth), the mouse E-sys is already well developed, as shown by a highly sensitive cell-coupling assay based on the combination of patch-clamp and voltage imaging (Fig. 2). The C-sys, which starts to develop around $\mathrm{P} 0$, is further subdivided into two subsystems comprising, on the one hand, fibrocytes of the spiral limbus and, on the other hand, fibrocytes of the lateral wall, basal and intermediate cells of the stria vascularis, fibrocytes of the suprastrial zone, mesenchymal cells lining the scala vestibuli, and supralimbal dark cells (Kikuchi et al. 1995, 2000a,b; Forge et al. 1999).

GJ plaques are not present in marginal cells of the stria vascularis (Forge et al. 2003a), a conclusion supported by dye-coupling experiments (Kelly et al. 2011). Likewise, GJs were never found in the plasma membrane of sensory hair cells (Forge et al. 2003a), consistent with absence of recovery after photobleaching (Majumder et al. 2010) in "gap-FRAP" cell-coupling assays (Wade et al. 1986) and in accord also with the requirements imposed on the plasma membrane conductance for the generation of hair cell receptor potentials (Dallos et al. 1982; Dallos 1986; Palmer and Russell 1986; Cody and Russell 1987; Mammano and Nobili 1993; Nobili and Mammano 1996; Mistrik et al. 2009; Mistrik and Ashmore 2010; Johnson et al. 2011; see also Ashmore 2018; Holt and Corey 2018; Petit 2018). 
A

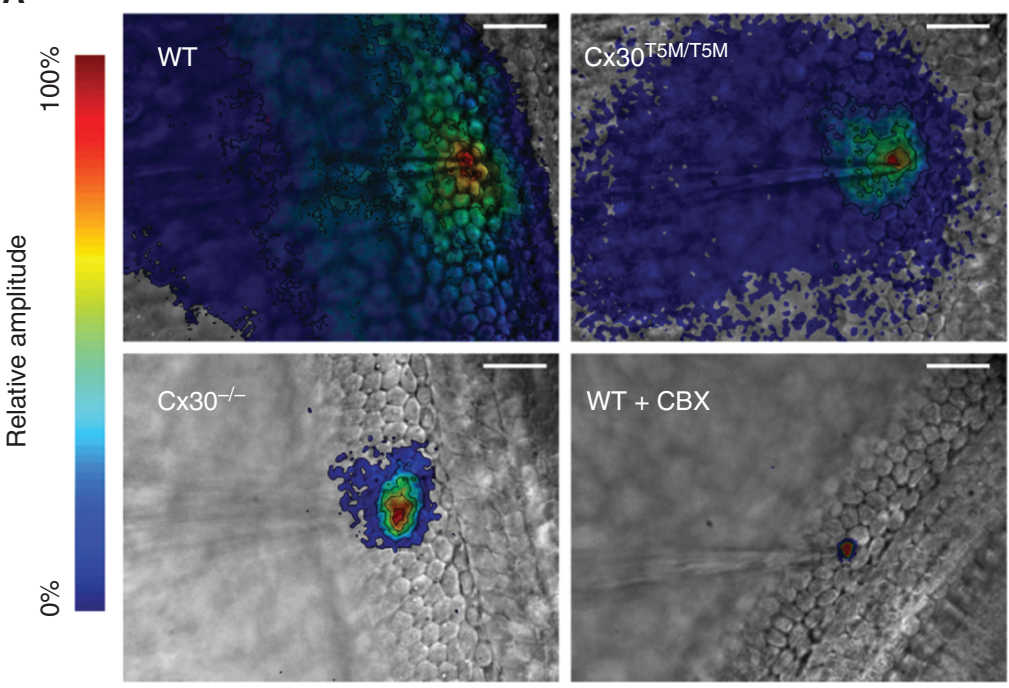

B

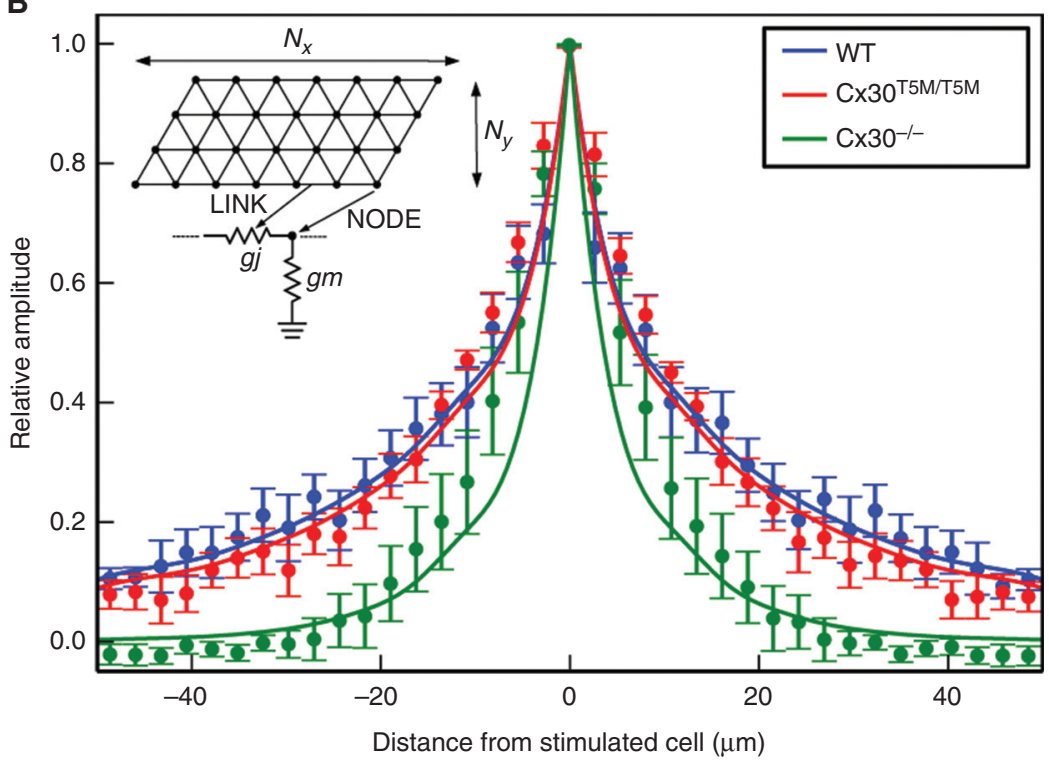

Figure 2. Network connectivity in the epithelial gap junction system (E-sys) of the developing mouse cochlea. (A) Representative false color images showing the spatial distribution of fluorescence signals generated by the voltage sensitive dye Vf2.1.Cl (Miller et al. 2012) in organotypic cochlear cultures from P5 wild-type (WT) (top left), Gjb6 ${ }^{\mathrm{T} 5 \mathrm{M} / \mathrm{T} 5 \mathrm{M}}$ (top right), and $\mathrm{Gjb6}^{-1-}$ (bottom left) mice; the bottom right image shows a wild-type culture in which GJ channels were blocked by 20 min incubation with carbenoxolone (CBX, $100 \mu \mathrm{M})$. (B) Data fit by a simple resistive network model that reflects the anatomy. For further details, see Ceriani and Mammano (2013).

Plaques containing $\sim 10^{4}$ channels are not infrequent among supporting cells of the organ of Corti, and some may contain in excess of $10^{5}$ channels (Forge et al. 2003a), of which 1\%-10\% are expected to be in the open state at any one time (Bukauskas et al. 2000; Palacios-Prado et al. 2009, 2010). Consistent with these estimates, the measured junctional currents in isolated pairs of 
F. Mammano

supporting cells of the adult guinea pig organ of Corti, up to $1 \mu \mathrm{S}$ (Santos-Sacchi 1991), are compatible with a number of open channels per cell pair of the order of $10^{4}$ (Ceriani and Mammano 2013), which permits the cell-to-cell diffusion of microinjected Lucifer yellow (Mammano et al. 1996; Jagger and Forge 2006), a fluorescent tracer vastly used for dye-coupling assays (Stewart 1978; Hanani 2012; Xu et al. 2017).

\section{CELL COUPLING AND NUTRIENT SUPPLY TO THE ORGAN OF CORTI}

The sensory epithelium of the mammalian cochlea is an essentially avascular structure. A single blood capillary, the vas spirale, runs in the tympanic layer of the basilar membrane just beneath the tunnel of Corti (Smith 1951; Kirikae et al. 1969). The rest of the blood supply relies on two networks of blood vessels: one serving the spiral limbus (Firbas et al. 1981) and the other serving the spiral ligament and stria vascularis (Ando and Takeuchi 1998; Cohen-Salmon et al. 2004, 2007). Spiral ligament vessels, which are embedded in the fibrocytes forming part of the C-sys, penetrate the stria vascularis in which they divide into numerous thin capillaries (Ando and Takeuchi 1998).

Blood glucose is exported via a facilitated transport system; in rats, its concentrations in perilymph of scala vestibuli, perilymph of scala tympani, and cerebrospinal fluid are $~ 50 \%$, and in endolymph $<10 \%$, of that in plasma (Ferrary et al. 1987). Intercellular coupling via GJs has been proposed to aid transfer glucose and other metabolites to all cells of the cochlear sensory epithelium (Santos-Sacchi and Dallos 1983). Glucose diffusion through the network of cochlear GJ-coupled cells has been documented using 2-(N-(7-nitrobenz-2-oxa-1,3-dia-zol4-yl)amino)-2-deoxyglucose (2-NBDG) (Chang et al. 2008), a fluorescent glucose analog that has been used to monitor glucose uptake in live cells (Zou et al. 2005). A similar role has been shown for astrocytes, in which GJ communication provides an activity-dependent intercellular pathway for the delivery of metabolites involved in energy production from blood vessels to distal neurons (Rouach et al. 2008).

\section{CONNEXIN EXPRESSION IN THE MAMMALIAN COCHLEA}

An in situ hybridization study reported strong and overlapping expression of Cx26, Cx30, $\mathrm{Cx} 30.2, \mathrm{Cx} 31, \mathrm{Cx} 37, \mathrm{Cx} 43, \mathrm{Cx} 46$ both in the organ of Corti and in the lateral wall of the mouse neonatal cochlea, whereas low expression was detected for Cx45 and Cx59 (Buniello et al. 2004). ${ }^{5}$ A cDNA microarray hybridization study identified a more limited number of four most prominent connexins expressed in the mouse cochlea, namely, Cx26, Cx29, Cx30, and Cx43 (Ahmad et al. 2003). A study based on immunofluorescence and electron microscopy in the adult cochlea of mice, guinea pigs, gerbils, and bats concluded that " $\mathrm{Cx} 26$ and $\mathrm{Cx} 30$ colocalized in supporting cells of the organ of Corti, in the basal cell region of the stria vascularis, and in type 1 fibrocytes of the spiral ligament. No other connexin was detected in these regions. Cx31 was localized among type 2 fibrocytes below the spiral prominence, a region where $\mathrm{Cx} 30$ was not expressed and Cx26 expression appeared to be low. Cx43 was detected only in the region of tension fibrocytes lining the inner aspect of the otic capsule" (Forge et al. 2003a).

Despite inconsistencies in the animal studies quoted above, there is widespread consensus that $\mathrm{Cx} 26$ and $\mathrm{Cx} 30$ are the prevailing connexins in both the E-sys and the C-sys of the developing and mature rodent cochlea (Kikuchi et al. 1995; Lautermann et al. 1998, 1999; Ahmad et al. 2003; Forge et al. 2003a,b; Zhao and Yu 2006). In mice, the coordinated regulation of Cx26 and Cx30 expression occurs as a result of signaling through the nuclear factor (NF)- $\kappa \mathrm{B}$ pathway and can be inhibited by expressing a stable form of the IкB repressor protein that prevents the activation/ translocation of NF- $\mathrm{KB}$ (Ortolano et al. 2008). Not only the expression of $\mathrm{Cx} 26$ and $\mathrm{Cx} 30$ is coordinately regulated, but, in addition, it has been claimed that heteromeric channels formed by $\mathrm{Cx} 26$ and $\mathrm{Cx} 30$ are present in the organ of Corti and lateral wall tissues of the rodent co-

${ }^{5}$ Note that there is no entry for (mouse) Cx59 in Table 1, therefore it is unclear what the authors referred to. 
chlea, and in the sensory epithelia of the vestibular system (Ahmad et al. 2003; Forge et al. 2003a,b). Studies performed with recombinant connexins indicate that $\mathrm{Cx} 26$ and $\mathrm{Cx} 30$ can indeed form functional heteromeric channels in cell lines (Sun et al. 2005; Yum et al. 2007). However, none of the immunofluorescence studies performed in rodents achieved the required spatial resolution to show convincingly that heteromeric Cx26/Cx30 connexons do exist in the cochlea. Actually, GJ plaques formed almost exclusively by Cx30 prevail in the Deiters' cell region of the P30 mouse cochlea (Jagger and Forge 2015). Furthermore, cell-specific distributions of Cx26 and Cx30 were reported in the guinea pig and rat cochlear lateral wall, in which Cx26 labeling was absent in the middle region just beneath the stria vascularis (Liu and Zhao 2008).

Recently, subdiffraction multicolor imaging (Gustafsson et al. 2008) of the lateral wall and sensory epithelium of the adult human cochlea achieved a resolution of $\sim 100 \mathrm{~nm}$ in the focal plane $(\mathrm{X}-\mathrm{Y})$ and an axial $(\mathrm{Z})$ resolution of $\sim 400$ nm (Liu et al. 2016, 2017). The investigators of those studies suggested that "CX26 and CX30 proteins are not coexpressed in the lateral wall of the human cochlea but, rather, form closely associated GJ plaques." In the organ of Corti, "CX26 subdomains appeared inside annular plaques" forming "hybrid plaques," supporting the notion that "diverse aggregates of GJ channels can populate the same GJ plaque or represent physically interacting plaques" (Liu et al. 2016, 2017). As shown by freeze-fracture replica immunogold labeling (Fujimoto 1995), a similar hybrid arrangement may characterize GJ plaques in rodent astrocytes, which express Cx26, Cx30, and Cx43 (Rash et al. 2001). In summary, the unresolved discrepancy between human and rodent studies prevents drawing a definitive conclusion regarding existence and relative importance of heteromeric versus homomeric GJ channels in the organ of Corti and lateral wall of the cochlea.

\section{CONNEXIN MUTATIONS AND HEREDITARY HEARING IMPAIRMENT}

Genetic studies have revealed the critical importance for human hearing of some of the connex- ins expressed in the inner ear. In particular, variants of the GJB2 (CX26) gene, ${ }^{6}$ which include more than 340 missense, nonsense, frame shift, insertions, and deletions, ${ }^{7}$ take the lion share in the spectrum of deafness related mutations. ${ }^{8}$ The overwhelming majority of them cause autosomal recessive nonsyndromic deafness 1a (DFNB1A; OMIM [Online Mendelian Inheritance in Man]:220290) (Kelsell et al. 1997; del Castillo and del Castillo 2017). These mutations, which account for $\sim 50 \%$ of all autosomal recessive nonsyndromic hearing impairment cases, ${ }^{9}$ are responsible for hearing loss ranging from mild to profound (Kenna et al. 2010), and are broadly classified as truncating (e.g., premature stop codons, associated with a significantly greater degree of hearing impairment), and nontruncating (e.g., missense variants) (Snoeckx et al. 2005). The truncating variant $35 \mathrm{delG}$ (Zelante et al. 1997), also known as 30delG (Denoyelle et al. 1997), halts CX26 transcription at the level of the amino terminus (Table 2), causing complete loss of protein function (D'Andrea et al. 2002). In a study that included 82 families (51 Italian and 31 Spanish) with nonsyndromic congenital deafness of different degrees, $35 \mathrm{delG}$ accounted for $85 \%$ of GJB2 variants (Estivill et al. 1998).

A restricted set of missense GJB2 variants cause autosomal dominant nonsyndromic deafness 3a (DFNA3A; OMIM:601544) (Denoyelle et al. 1998). The corresponding mutant CX26 proteins are thought to exert dominant-negative effects on wild-type CX26 or CX30 (Forge et al. 2003b; Zhang et al. 2011), whereas a distinct set of dominantly inherited missense mutations apparently modify the activity of both wild-type CX26 and CX43 (Rouan et al. 2001; Shuja et al. 2016), causing syndromic hearing impairment associated with a spectrum of skin disorders, including Keratitis-ichthyosis-deafness syndrome (KID; OMIM:148210) (Richard et al. 2002),

\footnotetext{
${ }^{6}$ http://swissvar.expasy.org/cgi-bin/swissvar/result?global_ textfield=gjb2\&findProteins=search.

${ }^{7} \mathrm{http}: / /$ deafnessvariationdatabase.org/letter/g, then select "GJB2".

${ }^{8}$ https://www.ncbi.nlm.nih.gov/books/NBK1434.

${ }^{9}$ https://www.ncbi.nlm.nih.gov/books/NBK1272.
} 


\section{F. Mammano}

Hystrix-like ichthyosis with deafness (HID; OMIM:602540) (van Geel et al. 2002), Keratoderma, palmoplantar, with deafness (PPK-D; OMIM:148350) (Richard et al. 1998b), Vohwinkel syndrome (VS; OMIM:124500) (Maestrini et al. 1999), and Bart-Pumphrey syndrome (BPS; OMIM:149200) (Richard et al. 2004).

Variants of the GJB3 (CX31) gene ${ }^{10}$ cause: (1) autosomal dominant deafness 2b (DFNA2B; $\mathrm{OMIM}^{11}: 612644$ ) (Xia et al. 1998); (2) digenic deafness (GJB2/GJB3; OMIM: 220290) (Liu et al. 2009); and (3) erythrokeratodermia variabilis et progressiva (OMIM:133200) (Richard et al. 1998a). Finally, variants of the GJB6 $(\text { CX30 })^{12}$ gene, which is located just $30 \mathrm{~kb}$ upstream of GJB2 in the same DFNB1 locus on chromosome 13 (del Castillo and del Castillo 2017) causes (1) autosomal recessive deafness $1 \mathrm{~b}$ (DFNB1B; OMIM:612645) (del Castillo et al. 2002); (2) autosomal dominant deafness 3b (DFNA3B, OMIM:612643) (Grifa et al. 1999); (3) digenic deafness (GJB2/GJB6, OMIM:220290) (Lerer et al. 2001; Pallares-Ruiz et al. 2002; del Castillo et al. 2005); and (4) ectodermal dysplasia 2, clouston type (OMIM:129500) (Lamartine et al. 2000).

The existence of a digenic pattern of inheritance is supported by the discovery of large deletions that truncate the GJB6 gene leaving GJB2 intact (Lerer et al. 2001; del Castillo et al. 2002, 2003, 2005; Pallares-Ruiz et al. 2002). One of these variants, del(GJB6-D13S1830), accounts for hearing impairment in $30 \%$ to $70 \%$ of affected GJB2 heterozygotes in some populations (del Castillo et al. 2005). Thus, it can be safely concluded that mutations in the genes that encode CX26 and CX30 are the predominant cause of prelingual hereditary deafness, and the most frequently encountered variants cause complete loss of protein function.

The connection between hearing loss and dermatological manifestations is not surprising,

${ }^{10} \mathrm{http} / / /$ swissvar.expasy.org/cgi-bin/swissvar/result?global_ textfield=gjb3\&findProteins $=$ search .

${ }^{11}$ Online Mendelian Inheritance in Man, https://www.omim .org/about.

${ }^{12}$ http://swissvar.expasy.org/cgi-bin/swissvar/result?global_ textfield=gjb6\&findProteins=search. as a number of inner ear connexins are expressed also in skin keratinocytes (Butterweck et al. 1994; Goliger and Paul 1994; Salomon et al. 1994; Di et al. 2001). However, variants of GJA1 (CX43) ${ }^{13}$ and GJB4 (CX30.3) ${ }^{14}$ cause skin disease without hearing loss (Lilly et al. 2016). Likewise, GJB2 somatic mutations of the KID type that occur only in keratinocytes cause Porokeratotic eccrine ostial and dermal duct nevus (PEODDN) without affecting hearing (Easton et al. 2012; Lazic et al. 2012). It has been suggested that diverse connexin mutations associated with distinct epidermal phenotypes consistently give rise to novel gain of function activities, including changes in hemichannel activity (Retamal et al. 2015; Lilly et al. 2016). This conclusion is supported by in vitro studies with connexin gene variants that cause cell death in expression systems, including some autosomal dominant syndromic mutants of GJB2 (Stong et al. 2006; Lee and White 2009; Sanchez et al. 2010, 2013, 2014, 2016; Mhaske et al. 2013; Press et al. 2017b; Xu et al. 2017), GJB3 (Di et al. 2002; He et al. 2005), and GJB6 (Essenfelder et al. 2004; Berger et al. 2014). Mouse models for human syndromic deafness associated with skin disorders (Mese et al. 2011; Schutz et al. 2011; Bosen et al. 2014; Press et al. 2017a) lend further support to this view (Garcia et al. 2016; Srinivas et al. 2018).

In the attempt to find a rationale for the pervasiveness of GJB2 mutations, it has been suggested that reduced CX26 expression in human skin may confer a selective advantage as heterozygous carriers of the GJB2 $35 \mathrm{delG}$ variant show significantly increased epidermal thickness, which may enhance protection against pathogen invasion or trauma compared with noncarriers (D'Adamo et al. 2009). In the same vein, in vitro models of infection showed "a significant reduction in both cellular invasion by Shigella flexneri and adherence by enteropathogenic Escherichia coli in human intestinal cell lines following treatment with CX26

\footnotetext{
${ }^{13}$ http://swissvar.expasy.org/cgi-bin/swissvar/result?global_ textfield $=$ gja $1 \&$ findProteins $=$ search .

${ }^{14}$ http://swissvar.expasy.org/cgi-bin/swissvar/result?global_ textfield=gjb4\&findProteins=search.
} 
Inner Ear Connexin Channels

siRNA," suggesting that heterozygous carriers may benefit also from increased gastrointestinal protection (Simpson et al. 2013).

\section{MOUSE MODELS FOR HUMAN NONSYNDROMIC DEAFNESS}

Embryonic lethality affects Cx26 homozygous knockout mice $\left(G j b 2^{\text {tm1Kwi }} / G j b 2^{\text {tm1Kwi }}\right.$; MGI [Mouse Genome Informatics] ${ }^{15}: 2155739$; EM [European Mouse Mutant Archive] $\left.{ }^{16}: 00229\right)$ because of impaired transplacental uptake of glucose (Gabriel et al. 1998). On the contrary, Cx30 homozygous knockout-LacZ mice (Gjb6 ${ }^{\mathrm{tm} 1 \mathrm{Kwi}}$ / Gjb6 ${ }^{\text {tm1Kwi }}$; MGI:2447863; EM:00323), abbreviated as $\mathrm{Gj} \mathrm{6}^{-/-}$, are viable and fertile, show a severe constitutive hearing impairment by auditory brainstem recordings (ABRs), completely lack the endocochlear potential (Teubner et al. 2003), show defects of the endothelial barrier in capillaries of the stria vascularis (CohenSalmon et al. 2007), and impaired transfer of the fluorescent D-glucose derivative 2-NBDG (Chang et al. 2008).

In $G j b 6^{-1-}$ mice, the Cx30 coding exon of Gjb6 was both removed and replaced by the lacZ reporter gene and a neo resistance cassette. This may interfere with expression of Gjb2 nearby, as Cx26 levels were severely reduced in the developing cochlea of $G j b 6^{-l-}$ mice (Ortolano et al. 2008). Likewise, "gene deletion of Cx30 led to the near total elimination of immunofluorescence labeling for Cx26 in all leptomeningeal tissues covering brain surfaces as well as in astrocytes of brain parenchyma" in these mice (Lynn et al. 2011).

A different $\mathrm{Cx} 30$ global knockout strain $\left(G j b 6^{\text {tm1.1Mcsa }} / G j b 6^{\text {tm1.1Mcsa }}\right.$; MGI:5486677), abbreviated as $G j b 6^{\Delta / \Delta}$, in which Gjb6 was deleted without insertion of lacZ and neo showed normal hearing thresholds. Residual expression of inner ear Cx26 was $\sim 50 \%$ in $G j b 6^{\Delta / \Delta}$ mice, but only $\sim 10 \%$ in $G j b 6^{-1-}$ mice, compared with $\mathrm{Gjb \sigma}^{+/+}$controls (Boulay et al.

${ }^{15}$ Mouse Genome Informatics, http://www.informatics.jax .org.

${ }^{16}$ European Mouse Mutant Archive (EMMA/INFRAFRONTIERS), https://www.infrafrontier.eu.
2013). Mice in which extra copies of Gjb2 were transgenically expressed from a modified bacterial artificial chromosome in a $G j b 6^{-1-}$ background $\left(G j b 6^{\mathrm{tm} 1 \mathrm{Kwi}} / G j b 6^{\mathrm{tm} 1 \mathrm{Kwi}} \mathrm{Tg}(G j b 2) 1 X i l i /\right.$ 0; MGI: 3713363) had normal hearing sensitivity (Ahmad et al. 2007). Altogether, these experiments have prompted the conclusion that (1) Cx30 is dispensable for auditory function, and (2) the hearing loss in $\mathrm{Gjb6}^{-/-}$mice depends only on reduction of $\mathrm{Cx} 26$ expression in the inner ear, below a certain critical level $(<50 \%)$ (Boulay et al. 2013).

The essential role played by $\mathrm{Cx} 26$ for mouse hearing was shown by cross-breeding mice with floxed $G j b 2$ exon $2\left(G j b 2^{\text {tm1Ugds }} / G j b 2^{\text {tm1Ugds }}\right.$ MGI:2183509; EM:00245), abbreviated as Gjb2 $2^{\text {loxP/loxP }}$, and Otog-Cre mice (Tg(Otog-cre) 1Ugds; MGI:2183511) (Cohen-Salmon et al. 2002). In Gjb2 $2^{\text {loxP/loxP } O t o g-C r e ~ o f f s p r i n g ~(M G I: ~}$ 3588875), abbreviated as Gjb2 ${ }^{\text {OtogCre }}, \mathrm{Cx} 26 \mathrm{im}$ munoreactivity was undetectable from birth onward in cells of the E-sys, but still present in fibrocytes of the C-sys. Similar hearing thresholds were measured in control $\left(G j b 2^{\text {loxP/loxP }}\right)$ mice and heterozygous $\mathrm{Gjb} 2^{\mathrm{loxP} /+} \mathrm{Otog}-\mathrm{Cre}$ mice, whereas thresholds were significantly elevated in (homozygous) Gjb2 $2^{\text {OtogCre }}$ mice, in which endocochlear potential was reduced $^{17}$ (Cohen-Salmon et al. 2002).

Subsequent loss of the Otog-Cre line promoted a search for alternative Cre-expressing lines. Cross-breeding Gjb2 $2^{\text {loxP/loxP }}$ mice and Sox10-Cre mice (Tg(Sox10-cre)1Wdr; MGI: 3586900 ) yielded Gjb2 $2^{\text {loxP/loxP }}$ Sox10-Cre offspring, abbreviated as tGjb2 $2^{-/-}$(MGI:5297177; EM:11478 $)^{18}$, that lacked Cx26 immunoreactivity in cells of the E-sys (Anselmi et al. 2008). Immunoreactivity for both $\mathrm{Cx} 26$ and $\mathrm{Cx} 30$ was still present in the cochlear lateral wall of adult $\mathrm{t} G j b 2^{-1-}$ mice, in which in vivo electrophysiological measurements revealed congenital profound hearing impairment, accompanied by a major reduction of the endocochlear potential

\footnotetext{
${ }^{17} \mathrm{http}: / /$ www.informatics.jax.org/allele/genoview/MGI: 3588 875 .

18 " $\mathrm{t}$ " stands for targeted; these mice were previously named Cx26 $6^{\text {Sox10Cre }}$, whereas their correct nomenclature is: $G j b 2^{\mathrm{tm} 1 \mathrm{Ugds}} / G j b 2^{\mathrm{tm} 1 \mathrm{Ugds}} \mathrm{Tg}($ Sox $10-$ cre $) 1 \mathrm{Wdr} / 0$.
} 
F. Mammano

Table 3. List of main mouse models mentioned in text

\begin{tabular}{|c|c|c|}
\hline Abbreviation(s) & Allele composition & Identifier \\
\hline$G j b 2^{\operatorname{loxP} / \operatorname{loxP}}$ & $G j b 2^{\mathrm{tm} 1 \mathrm{Ugds}} / G j b 2^{\mathrm{tm} 1 \mathrm{Ugds}}$ & MGI:2183509; EM:00245 \\
\hline Otog-Cre & $\operatorname{Tg}($ Otog-cre $) 1$ Ugds & MGI:2183511 \\
\hline Sox10-Cre & $\operatorname{Tg}($ Sox $10-$ cre $) 1 W \mathrm{dr}$ & MGI:3586900 \\
\hline Gjb2 $2^{\text {OtogCre }}$ & $G j b 2^{\text {tm1Ugds }} / G j b 2^{\text {tm1Ugds }} \mathrm{Tg}($ Otog-cre $) 1$ Ugds $/ 0$ & MGI: 3588875 \\
\hline $\mathrm{t} G j b 2^{-1-}\left(C \times 26^{\text {Sox10Cre }}\right)$ & $G j b 2^{\mathrm{tm} 1 \mathrm{Ugds}} / G j b 2^{\mathrm{tm} 1 \mathrm{Ugds}} \mathrm{Tg}($ Sox $10-\mathrm{cre}) 1 \mathrm{Wdr} / 0$ & MGI:5297177; EM:11478 \\
\hline$G j b 6^{-1-}$ & $G j b 6^{\mathrm{tm} 1 \mathrm{Kwi}} / G_{j b} 6^{\mathrm{tm} 1 \mathrm{Kwi}}$ & MGI:2447863; EM:00323 \\
\hline$G j b 6^{\Delta / \Delta}$ & $G j b 6^{\mathrm{tm} 1.1 \mathrm{Mcsa}} / G j b 6^{\mathrm{tm} 1.1 \mathrm{Mcsa}}$ & MGI:5486677 \\
\hline$G j b 6^{\mathrm{T} 5 \mathrm{M} / \mathrm{T} 5 \mathrm{M}}$ & $G j b 6^{\mathrm{tm} 1.1 \mathrm{Fama}} / G j b 6^{\mathrm{tm} 1.1 \mathrm{Fama}}$ & MGI:4848154; EM:05214 \\
\hline
\end{tabular}

(Crispino et al. 2011). Table 3 provides a summary of the abbreviations used to identify mouse models most frequently mentioned in in this review.

The sensory epithelium of the developing cochlea is subdivided into two embryologically distinct regions, the greater epithelial ridge (GER) and the lesser epithelial ridge (LER), which are separated by a pair of immature inner and outer pillar cells (Eggston and Wolff 1947; Lim and Anniko 1985; Lim and Rueda 1992). The GER encompasses the nascent inner sulcus, the tall columnar cells of the so-called Kölliker's organ (Hinojosa 1977), the inner hair cells (IHCs), and their abutting supporting cells (Bryant et al. 2002; Kelley 2007; see also Montcouquiol and Kelley 2018). Postnatal maturation of pillar cells leads to the opening of the tunnel of Corti and a progressive increase in the distance between the IHCs and the outer hair cells (OHCs). In the basal turn of the cochlea, the tunnel of Corti and Nuel's space were open at P6 in control mice (C57BL6/N), but failed to open in $\mathrm{t} G j b 2^{-/-}$mice, indicative of developmental defects. Consistent with this conclusion, Cx30 expression was developmen-

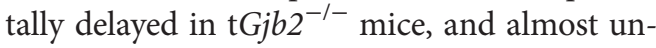
detectable in cells of the epithelial network during the first postnatal week (Crispino et al. 2011).

Irreversible cell loss in the organ of Corti was detected either before or around the onset of hearing (P12) in both Gjb2 $2^{\text {OtogCre }}$ and $\mathrm{t} G j b 2^{-/-}$ mice. In the latter, degeneration of the sensory epithelium affected both sensory and nonsensory cells of the basal turn at P30 (Crispino et al. 2011). In GJB2 ${ }^{\text {OtogCre }}$ mice, detection of apoptosis by the TUNEL assay, and immunofluorescence detection of activated caspase 3 , showed labeling of the two supporting cells flanking the IHCs (i.e., border cell and inner phalangeal cell) from P14 onward. Labeling extended to OHCs and their supporting cells (Deiters' and Hensen's cells) by P16 onward (CohenSalmon et al. 2002).

The deafness phenotype was more severe in $\mathrm{tGj} b 2^{-/-}$mice than in Gjb2 $2^{\text {OtogCre }}$ mice, most likely a result of the different Cre drivers used to generate these mice. Indeed, an even more dramatic hearing loss and cellular degeneration phenotype affected Gjb2 $2^{\text {loxP/loxP }} \mathrm{R} 26$ cre-ER ${ }^{\mathrm{T}}$ offspring (EM:11488), in which Cre expression was activated globally by a single injection, on embryonic day 19, of the synthetic estrogen 4-hydroxytamoxifen (Sun et al. 2009). Two more lines were generated by cross-breeding $G j b 2^{\text {loxP/loxP }}$ mice with Foxg1-cre and Pax2-cre drivers, respectively, and both displayed sign of developmental disturbance, as well as dramatic loss of the OHCs and surrounding supporting cells around P13 (Wang et al. 2009). However, a note of caution is mandatory. Although Sox 10-cre mice are viable and have normal hearing thresholds, homozygous Foxg1-cre mice die perinatally (Tian et al. 2012). Furthermore, some Cre driver lines used for conditional gene deletion/expression in the inner ear (Cox et al. 2012) were recently reported with an early-onset progressive hearing loss, which was absent in their wild-type littermates (Matern et al. 2017), suggesting that the inner ear may be particularly vulnerable to expression of the bacterial Cre recombinase.

Pending demonstration that Cre-related toxicity effects (Loonstra et al. 2001) can be ex- 
cluded for the mouse models described above, it seems reasonable to conclude that (1) ablation of $\mathrm{Cx} 26$ in the cochlea is associated with downregulation of $\mathrm{Cx} 30$; (2) affects hair cell survival despite the fact that hair cells do not express any connexin; and (3) plays a critical role in organ of Corti development and acquisition of hearing. This conclusion is in reasonable agreement with reports of biallelic carriers of pathogenic GJB2 variants, whose hearing thresholds were normal at birth but deteriorated during the first year of life (Orzan and Murgia 2007; Gopalarao et al. 2008; Minami et al. 2013).

\section{CRITICAL ROLE FOR ATP- AND CONNEXIN-DEPENDENT INTERCELLULAR $\mathrm{Ca}^{2+}$ SIGNALING IN THE DEVELOPING COCHLEA}

Extracellular adenosine trisphosphate $\left(\mathrm{ATP}_{\mathrm{e}}\right)$ is a neurohumoral agent (Housley et al. 2009) that modulates the function of both sensory and nonsensory cells in the inner ear (Ashmore and Ohmori 1990; Dulon et al. 1991, 1993; Housley and Ashmore 1992; Housley et al. 1992, 2009, 2013; Sugasawa et al. 1996; Mammano et al. 1999; Lagostena and Mammano 2001; Lagostena et al. 2001; Frolenkov et al. 2003; Frolenkov 2006; Yan et al. 2013). In the developing cochlea, $\mathrm{ATP}_{\mathrm{e}}$ triggers $\left[\mathrm{Ca}^{2+}\right]_{\mathrm{c}}$ oscillations and propagation of intercellular $\mathrm{Ca}^{2+}$ waves that convey crucial biochemical information to every district of the cochlear sensory epithelium (Gale et al. 2004; Beltramello et al. 2005; Zhang et al. 2005; Piazza et al. 2007; Tritsch et al. 2007). Purinergic signaling is terminated by ectonucleotidases, expressed at the endolymphatic surface of the organ of Corti (Housley et al. 2002; Vlajkovic et al. 2004), which degrade $\mathrm{ATP}_{\mathrm{e}}$ (Zimmermann et al. 2012). $\mathrm{Ca}^{2+}$ wave propagation requires $\mathrm{ATP}_{\mathrm{e}}$ binding to $\mathrm{G}_{\mathrm{q} / 11}$-coupled $\mathrm{P}_{2} \mathrm{Y}$ receptors that activate a canonical intracellular signal transduction cascade, leading to diacylglycerol and inositol-1,4,5-trisphosphate $\left(\mathrm{IP}_{3}\right)$ generation from phospholipase $\mathrm{C}_{\beta}\left(\mathrm{PLC}_{\beta}\right)$-dependent hydrolysis of phosphatidylinositol 4,5-bisphosphate $\left(\mathrm{PIP}_{2}\right)$ (Okamura et al. 2001; Abbracchio et al. 2006; Kadamur and Ross 2013). Intracellular diffusion of $\mathrm{IP}_{3}$ and subsequent binding to $\mathrm{IP}_{3}$ receptors triggers $\mathrm{Ca}^{2+}$ release from the ER (Berridge 2009), raising the $\left[\mathrm{Ca}^{2+}\right]_{c}$ to peak levels of $\sim 500 \mathrm{~nm}$ (Beltramello et al. 2005; Ceriani et al. 2016b). ATP is found at millimolar concentration in the cytoplasm of most cells (Imamura et al. 2009), and the $\mathrm{Ca}^{2+}$-dependent increase in the open probability of connexin hemichannels (De Vuyst et al. 2006, 2009; Zhang et al. 2006; Leybaert et al. 2017; Carrer et al. 2018; $\mathrm{Hu}$ et al. 2018) favors the release of ATP from cytosol to extracellular milieu (Anselmi et al. 2008; Majumder et al. 2010). Thus, ATP-dependent ATP release enables the regenerative cellto-cell propagation of $\mathrm{Ca}^{2+}$ signals across the network of cochlear nonsensory cells by exploiting a cascade of biochemical reactions governed by critical phenomena that control also the frequency of intracellular $\left[\mathrm{Ca}^{2+}\right]_{c}$ oscillation $(\mathrm{Ce}-$ riani et al. 2016b).

In the LER, nonsensory cells develop spontaneous $\left[\mathrm{Ca}^{2+}\right]_{\mathrm{c}}$ oscillations when exposed to ARL 67156 (Anselmi et al. 2008), an ectonucleotidase inhibitor (Levesque et al. 2007), indicating that ATP is rapidly degraded by ectonucleotidases in the absence of the inhibitor. In the GER, spontaneous $\left[\mathrm{Ca}^{2+}\right]_{\mathrm{C}}$ transients arise periodically (suggesting that ectonucleotidase activity is constitutively reduced compared with the LER) and propagate as $\mathrm{Ca}^{2+}$ waves that reach the IHCs (Tritsch et al. 2007).

Flufenamic acid, a nonspecific blocker of connexin channels (Verselis and Srinivas 2013; Willebrords et al. 2017) blocks both $\mathrm{Ca}^{2+}$ waves in the LER (Anselmi et al. 2008), and spontaneous $\mathrm{Ca}^{2+}$ signaling activity in the GER (Schutz et al. 2010; Mammano and Bortolozzi 2018). The latter is also inhibited by a monoclonal antibody that binds the EC1 loop of Cx26 and blocks hemichannels, but not GJ channels (Xu et al. 2017). Other pharmacological interference experiments (Piazza et al. 2007; Rodriguez et al. 2012) with (1) thapsigargin, a noncompetitive inhibitor of the $\mathrm{Ca}^{2+}$-ATPase (SERCA) that causes the complete and irreversible depletion of $\mathrm{Ca}^{2+}$ from the ER, (2) the PLC inhibitor U73122, and (3) the $\mathrm{IP}_{3} \mathrm{R}$ antagonist 2-aminoethoxydiphenyl borate (2-APB), indicate that ATP-dependent $\mathrm{Ca}^{2+}$ signaling in the 


\section{F. Mammano}

GER and the LER are both mediated by the $\mathrm{PIP}_{2} \rightarrow \mathrm{PLC} \rightarrow \mathrm{IP}_{3}$ signaling cascade described above. This conclusion is also supported by $\mathrm{Ca}^{2+}$ imaging in the LER and the GER of mice with reduced expression of phosphatidylinositol-4-phosphate 5-kinase, type 1 gamma (Pip5k1c ${ }^{+/-}$; MGI:3054978) (Rodriguez et al. 2012), a key enzyme that generates $\mathrm{PIP}_{2}$ by phosphorylation of PI(4)P (Di Paolo et al. 2004).

$\mathrm{Ca}^{2+}$ waves failed to propagate in the developing sensory epithelium of $\mathrm{Gjb}^{-/-}$and

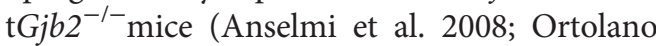
et al. 2008; Rodriguez et al. 2012), both of which failed to acquire hearing (Teubner et al. 2003; Crispino et al. 2011), whereas waves propagated normally in mice that were global knockouts for molecular components of alternative ATP release conduits (Pellegatti et al. 2005; Suadicani et al. 2006; Huang et al. 2007), such as $P 2 r x 7^{-/-}$ mice (MGI:3606250) and Pan $x 1^{-/-}$mice (EM:11476; MGI:5297171), both of which had hearing thresholds indistinguishable from those of their wild-type $(+/+$ ) siblings (Fig. 3) (see also Zorzi et al. 2017).

Bovine adeno-associated virus (BAAV) has a shown high tropism for nonsensory cells of
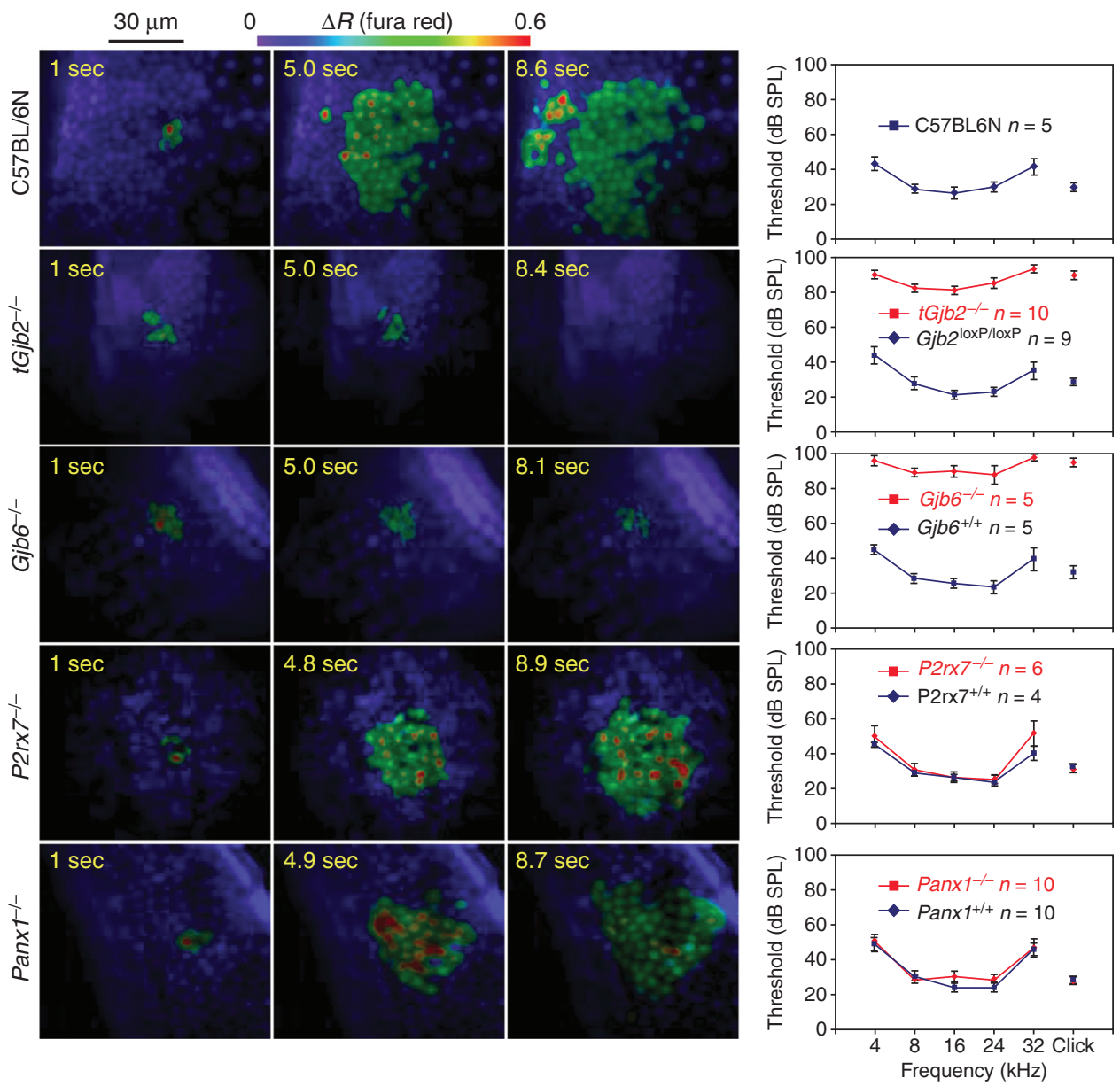

Figure 3. $\mathrm{Ca}^{2+}$ signals evoked by $100 \mathrm{msec}$ focal photostimulation with caged $\mathrm{IP}_{3}$ fail to propagate in connexin deficient cochlear cultures but propagate normally in $P 2 r x 7^{-/-}$and $P a n x 1^{-/-}$cultures. False-color images show $\mathrm{Ca}^{2+}$ signals in cochlear supporting and epithelial cells from P3-P6 mouse organotypic cultures coloaded with the $\mathrm{AM}$ esters of fura red and caged $\mathrm{IP}_{3}$. The corresponding audiograms were measured by auditory brainstem recordings (ABRs) in adult mice (P30-P45). For further details, see Anselmi et al. (2008) and Zorzi et al. (2017). 
rodent inner ear (Di Pasquale et al. 2005; Di Pasquale and Chiorini 2006; Shibata et al. 2009; Sheffield et al. 2011). Viral transduction with BAAV vectors encoding Cx30 restored $\mathrm{Cx} 30$ expression as well as $\mathrm{Ca}^{2+}$ wave propagation in cochlear organotypic cultures from P5 $\mathrm{Gj} 6^{-1-}$ mice (Ortolano et al. 2008). In vivo transduction with BAAV vectors encoding Cx30 via canalostomy in $\mathrm{P} 4 \mathrm{Gjb} 6^{\Delta / \Delta}$ mice promoted formation of Cx30 GJs and improved slightly but significantly hearing thresholds (measured around P30) of injected mice compared with noninjected controls (Crispino et al. 2017). In contrast, hearing thresholds were elevated by $\sim 15 \mathrm{~dB}$ sound pressure level (SPL) around P30 in wild-type (C57BL6) mice that had received a single shot of flufenamic acid via canalostomy at $\mathrm{P} 4$, whereas mice injected with artificial endolymph (vehicle) were not affected (Rodriguez et al. 2012). Similarly, elevated thresholds were also measured in a mouse model for a DFNA3 mutation (Gjb6 $6^{\mathrm{T} 5 \mathrm{M} / \mathrm{T} 5 \mathrm{M}}$; MGI:4848154; EM:05214), in which spontaneous $\mathrm{Ca}^{2+}$ signaling was slightly albeit significantly reduced in the GER at P5 compared with $\mathrm{Gjb6}^{+/+}$controls (Schutz et al. 2010).

The propagation of intercellular $\mathrm{Ca}^{2+}$ waves is accompanied by crenation of GER tall columnar cells (Tritsch et al. 2007), which is thought to depend on osmotic cell shrinkage by TMEM16A $\mathrm{Ca}^{2+}$-activated chloride channel opening. Release of chloride through these channels, which are highly expressed by supporting cells adjacent to IHCs, also forces $\mathrm{K}^{+}$ efflux that has been proposed to depolarize transiently the IHCs (Wang et al. 2015). Depolarization increases the frequency with which prehearing IHCs spontaneously generate $\mathrm{Ca}^{2+}$ action potentials (APs) (Kros et al. 1998; Beutner and Moser 2001) that trigger exocytosis (Glowatzki and Fuchs 2000). Optical detection of spontaneous AP activity by confocal $\mathrm{Ca}^{2+}$ imaging in cochlear organotypic cultures has been shown (Ceriani et al. 2016a). The biophysical properties and distribution of $\mathrm{K}^{+}$currents change dramatically during postnatal development in IHCs, which gradually lose the ability to fire $\mathrm{Ca}^{2+}$ APs (Kros et al. 1998; Marcotti et al. 2003) and produce instead graded receptor po- tentials in response to hair bundle stimulation (Beurg et al. 2006; Wu et al. 2017).

Most afferent nerve fibers innervate a single IHC by P12, guaranteeing that the place-frequency tonotopic map forms independently of sound-evoked neural activity (Sher 1971; Rubel and Fritzsch 2002; Echteler et al. 2005; Bulankina and Moser 2012). Thus, genetically encoded guidance is primarily responsible for initial targeting and segregation of inputs in auditory nuclei, whereas patterned spontaneous activity in immature IHCs is thought to provide essential clues for postnatal refinements in spiral ganglion connectivity before hearing onset (Tritsch et al. 2010; Clause et al. 2014).

These modifications are paralleled by functional maturation of synapses formed by IHCs with afferent fibers (Johnson et al. 2013a,b; see also Marcotti and Safieddine 2018). IHC afferent synapses present electron-dense body, surrounded by tethered vesicles (Safieddine et al. 2012; Wichmann and Moser 2015), which changes progressively the shape from spherical to an elongated "ribbon"-like structure during the first two postnatal weeks (Sobkowicz et al. 1982). Ribbon synapses failed to mature in IHCs of both Gjb2 $2^{\text {OtogCre }}$ mice and Gjb6 $6^{-/-}$mice (Cohen-Salmon et al. 2002; Johnson et al. 2017). Recall that Cx30 is absent, and Cx26 is massively down-regulated during cochlear postnatal development in $\mathrm{Gj} \mathrm{b} 6^{-/-}$mice (Ortolano et al. 2008; Boulay et al. 2013). In addition, ATP-dependent $\mathrm{Ca}^{2+}$ activity was impaired in $\mathrm{Gjb}^{-/-}$ cochlear organotypic cultures (Fig. 4) (Anselmi et al. 2008; Ortolano et al. 2008; Rodriguez et al. 2012). Patch clamp recordings in $\mathrm{Gjb}^{-/-} \mathrm{IHCs}$ revealed a comprehensive brake in IHC development, as basolateral membrane currents retained a prehearing phenotype (Fig. 5) (Johnson et al. 2017). Maturation of IHCs was partially prevented also in $\mathrm{t} G j b 2^{-/-}$mice, in which $\mathrm{Cx} 26$ was deleted from the E-sys but retained, with $\mathrm{Cx} 30$, in the C-sys, and was almost normal in $G j b 6^{\Delta / \Delta}$ mice, which lack Cx30 altogether but retain $\sim 50 \% \mathrm{Cx} 26$ in the cochlea (Johnson et al. 2017). Analysis of the unrelated Cx26 conditional KO mouse Gjb2 $2^{\text {loxP/loxP }}$ Prox1-CreER $\mathrm{ER}^{\mathrm{T} 2}$, suggests that connexin expression in the organ of Corti may be critical also for $\mathrm{OHC}$ functional 
F. Mammano
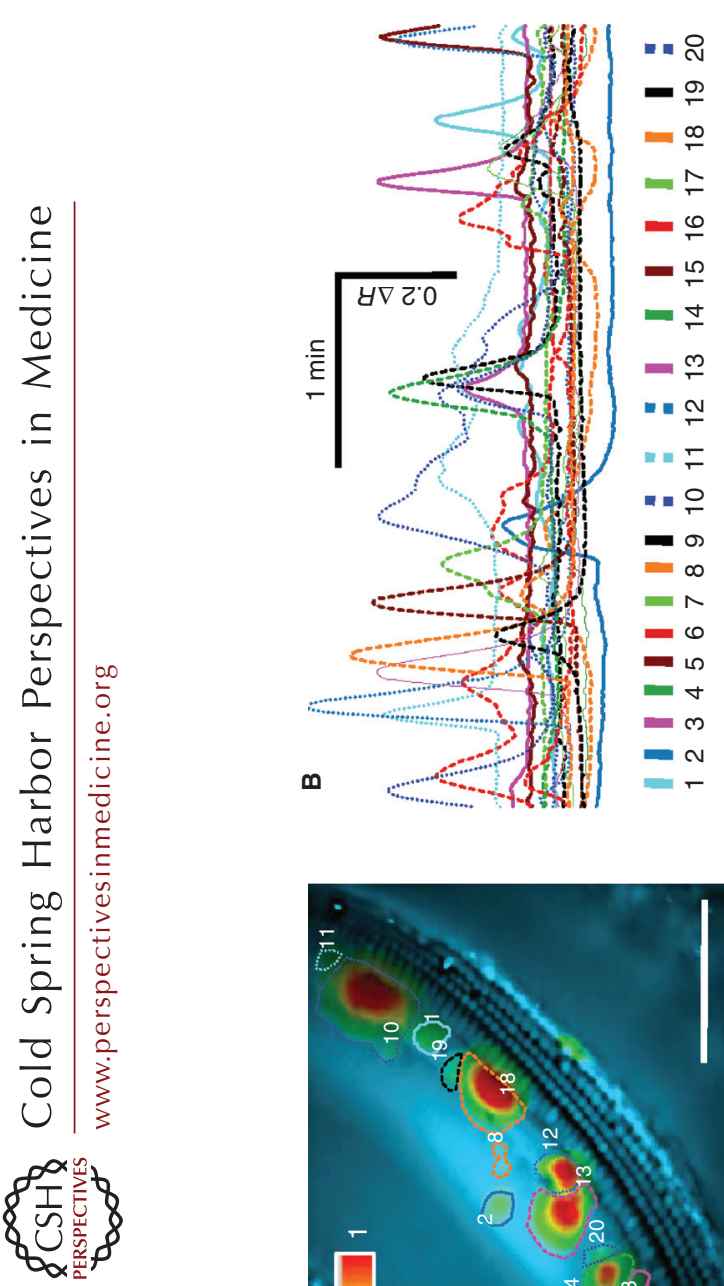

○

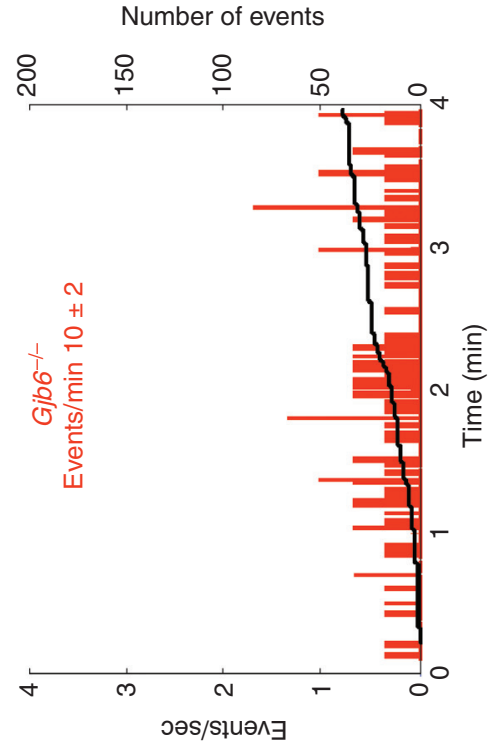

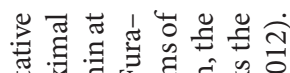

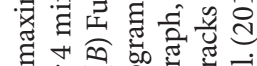

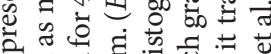

थे चु

క. छै

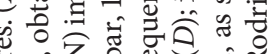

艺艺昰式

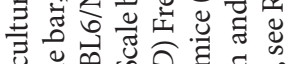

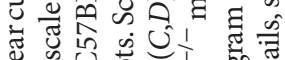

击

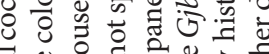

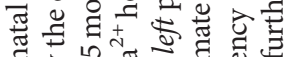

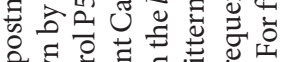

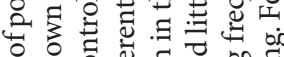

孚出

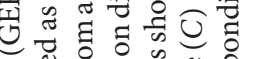

क्ष

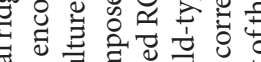
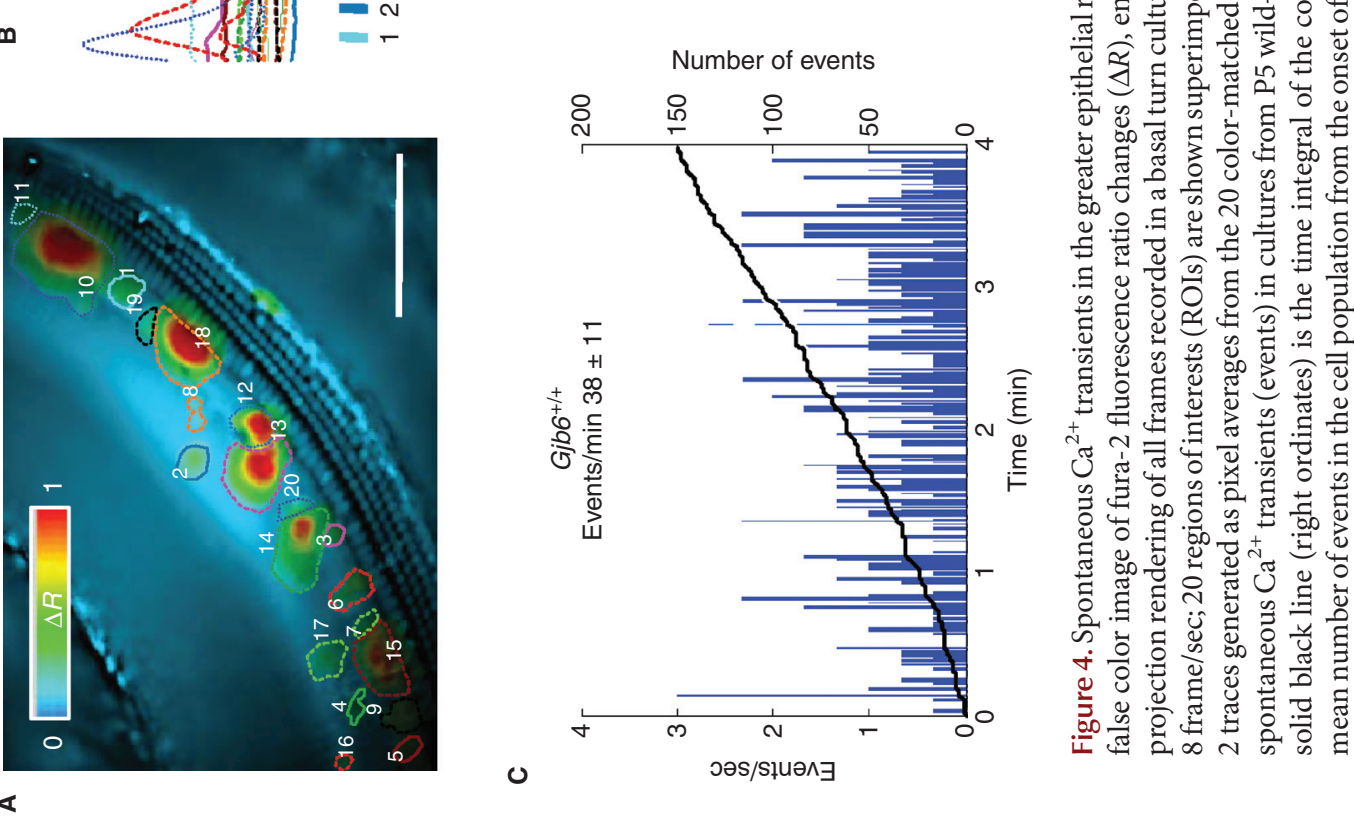

0

更

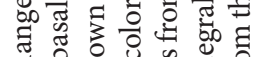

पे के

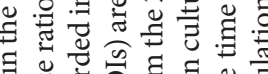

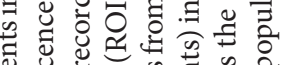

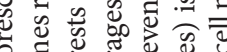

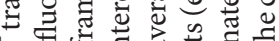
ช 灵

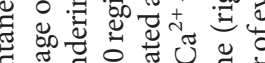

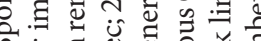

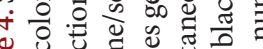

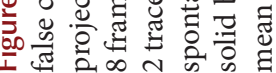
$\varangle$ 
Inner Ear Connexin Channels

A

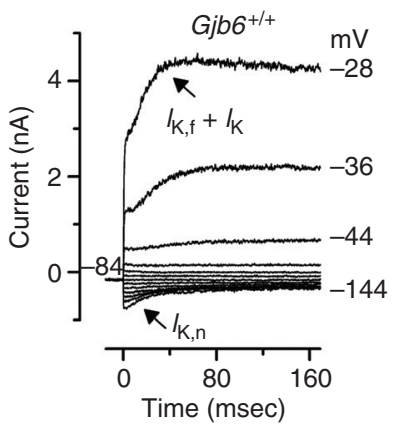

C
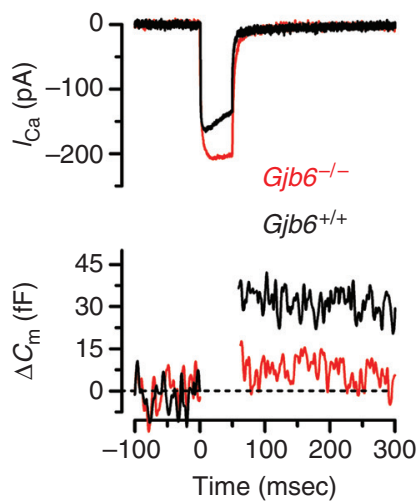

E

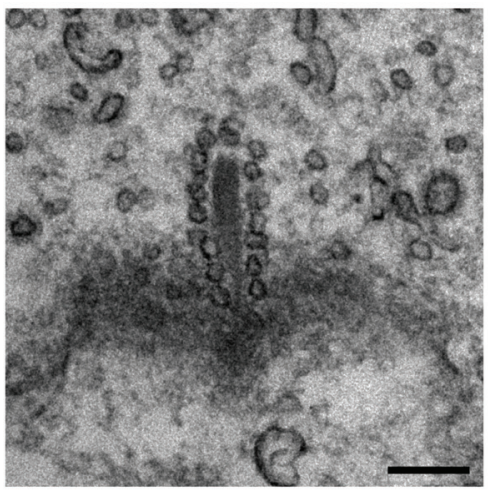

B

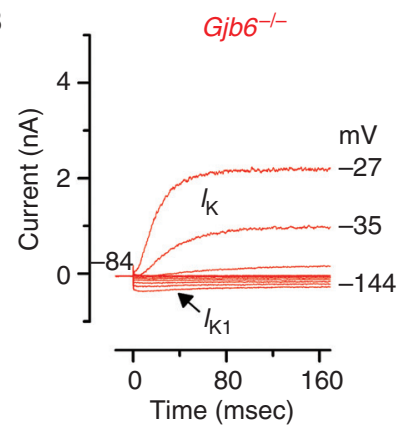

D

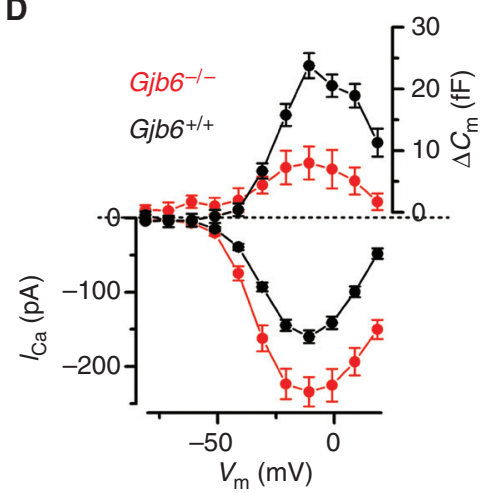

$\mathbf{F}$

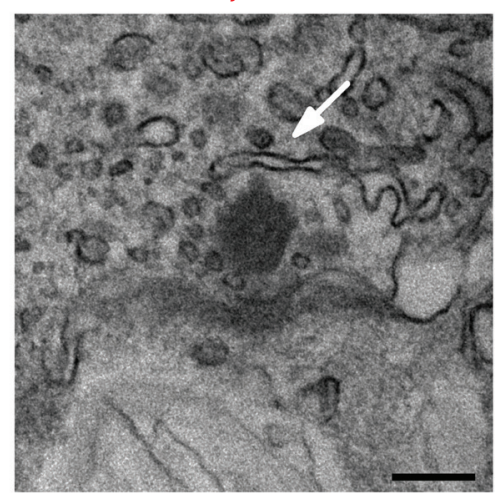

Figure 5. Membrane currents, exocytosis, and ribbon morphology in inner hair cells (IHCs) of $\mathrm{Gjb}^{-/-}$mice. $(A, B)$ Potassium currents recorded from P18 IHCs of wild-type $(A)$ and littermate $G j b 6^{-1-}(B)$ mice using depolarizing voltage steps in $10 \mathrm{mV}$ nominal increments from the holding potential of $-84 \mathrm{mV}$ to the various test potentials shown by some of the traces. The adult-type currents $\left(I_{\mathrm{K}, \mathrm{f}}\right.$ and $\left.I_{\mathrm{K}, \mathrm{n}}\right)$ were only present in IHCs from wild-type mice $(A)$. IHCs from $\mathrm{Gjb}^{-1-}$ mice retained the currents characteristic of immature cells $\left(I_{\mathrm{K}, \mathrm{s}}\right.$ and $\left.I_{\mathrm{K} 1}\right)$. (C) Calcium current, $I_{\mathrm{Ca}}$, and corresponding change in membrane capacitance, $\Delta C_{\mathrm{m}}$, recorded from adult control and $\mathrm{Gjb6}^{-1-}$ IHCs obtained in response to $50 \mathrm{msec}$ voltage steps, in $10 \mathrm{mV}$ increments, from $-81 \mathrm{mV}$. For clarity, only maximal responses at $-11 \mathrm{mV}$ are shown in panel C. (D) Average peak $I_{\mathrm{Ca}}$ (bottom panel) and $\Delta C_{\mathrm{m}}$ (top panel) curve from control (P17-25, $\left.n=15\right)$ and $\mathrm{Gjb6}^{-1-}(\mathrm{P} 18-24, n=5)$ IHCs. $(E, F)$ Typical cross-sectional profiles of synaptic ribbons obtained from a control $(E)$ and a $\mathrm{Gjb}^{-1-}(F)$ IHC. Note that some of the synaptic vesicles are missing around the ribbon of the $\mathrm{Gjb}^{-1-}$ IHC (arrow). Scale bar, $200 \mathrm{~nm}$. For further details, see Johnson et al. (2017). 
F. Mammano

maturation (Zhu et al. 2013). Taken together, these results provide compelling evidence that the delicate and tightly intertwined relationship between Cx26/Cx30 expression and ATP-dependent intercellular $\mathrm{Ca}^{2+}$ signaling in the postnatal cochlea plays a fundamental role for hearing acquisition.

\section{CONNEXINS AND MAINTENANCE OF COCHLEAR FUNCTION}

In vivo injection of a BAAV vector encoding a bacterial Cre recombinase via canalostomy in adult Gjb2 $2^{\text {loxP/loxP }}$ mice promoted Cre/LoxP recombination in nonsensory cells of the cochlear duct, resulting in decreased $\mathrm{Cx} 26$ expression (particularly in fibrocytes of the spiral ligament), decreased endocochlear potential, increased hearing thresholds (by as much as $60 \mathrm{~dB}$ SPL at $20 \mathrm{kHz}$ ), and $>90 \%$ loss of OHCs. No effect was observed after delivery of this vector to control C57BL6/N mice, therefore these results indicate that $\mathrm{Cx} 26$ expression is essential also for maintenance of cochlear function in the adult cochlea (Crispino et al. 2017). As mentioned previously, reduced GJ coupling may limit the transfer of nutrients, and glucose in particular, from distant blood vessels to the avascular sensory epithelium. In turn, nutrient deficiency impacts on ATP production, leading to reactive oxygen species (ROS) overload and apoptosis (Zhao et al. 2017), whereas massive loss of cytosolic ATP triggers necrosis in several cell types (Leist et al. 1997). This offers, in particular, a mechanistic explanation for the massive loss of OHCs because of their elevated mitochondrial metabolism (Jensen-Smith et al. 2012), which makes them particularly vulnerable to depletion of intracellular ATP levels. The role played by insufficient expression of $\mathrm{Cx} 26$ in redox imbalance, dysregulation of the Nrf2 pathway and etiopathogenesis of presbycusis has been further explored in a recent article (Fetoni et al. 2018).

\section{CONCLUDING REMARKS}

Genetic studies in humans have uncovered a critical for hearing role played by inner ear con- nexins, particularly CX26, CX30, and CX31. Mouse models have confirmed that Cx26 is essential for hearing. Indeed, ablation of $\mathrm{Cx} 26$ in the cochlea is associated with down-regulation of Cx30 and affects not only hair cell survival but also the normal development of the organ of Corti. However, studies of connexin channel composition have provided conflicting results in humans and mice.

Although the exact function of inner ear connexin remains incompletely undefined, there is compelling evidence that the networks of GJ channels they form supply the virtually avascular sensory epithelium with glucose and possibly other key metabolites. In addition, connexin hemichannels play a fundamental paracrine function in the developing cochlea, in conjunction with extracellular P2Y receptors and intracellular $\mathrm{IP}_{3}$ receptors, enabling the propagation of intercellular $\mathrm{Ca}^{2+}$ waves, influencing hair cell maturation and wiring of the organ of Corti. A recent review has also explored the potential role played by these connexin-dependent $\mathrm{Ca}^{2+}$-signaling mechanisms in sculpting the auditory sensory epithelium into its terminally functional shape through autophagy and apoptosis (Mammano and Bortolozzi 2018).

\section{ACKNOWLEDGMENTS}

This work was supported by Consiglio Nazionale delle Ricerche (CNR) Progetto di Interesse Invecchiamento (Grant DSB.AD009.001.004/ INVECCHIAMENTO-IBCN) and Fondazione Telethon (Grant GGP13114). Figure 1 was generated by Dr. Francesco Zonta. Audiograms in Figure 3 were generated by Ms. Veronica Zorzi using data collected in the author's laboratory. The author thanks the editors for helpful comments on a preliminary version of this review.

\section{REFERENCES}

* Reference is also in this collection.

Aasen T, Johnstone S, Vidal-Brime L, Lynn KS, Koval M. 2018. Connexins: Synthesis, post-translational modifications, and trafficking in health and disease. Int J Mol Sci 19: E1296. 
Abbracchio MP, Burnstock G, Boeynaems JM, Barnard EA, Boyer JL, Kennedy C, Knight GE, Fumagalli M, Gachet C, Jacobson KA, et al. 2006. International Union of Pharmacology LVIII: Update on the P2Y G protein-coupled nucleotide receptors: From molecular mechanisms and pathophysiology to therapy. Pharmacol Rev 58: 281-341.

Abney JR, Braun J, Owicki JC. 1987. Lateral interactions among membrane proteins. Implications for the organization of gap junctions. Biophys J 52: 441-454.

Ahmad S, Chen S, Sun J, Lin X. 2003. Connexins 26 and 30 are co-assembled to form gap junctions in the cochlea of mice. Biochem Biophys Res Commun 307: 362-368.

Ahmad S, Tang W, Chang Q, Qu Y, Hibshman J, Li Y, Sohl G, Willecke K, Chen P, Lin X. 2007. Restoration of connexin 26 protein level in the cochlea completely rescues hearing in a mouse model of human connexin30-linked deafness. Proc Natl Acad Sci 104: 1337-1341.

Ando M, Takeuchi S. 1998. Postnatal vascular development in the lateral wall of the cochlear duct of gerbils: Quantitative analysis by electron microscopy and confocal laser microscopy. Hear Res 123: 148-156.

Anselmi F, Hernandez VH, Crispino G, Seydel A, Ortolano S, Roper SD, Kessaris N, Richardson W, Rickheit G, Filippov MA, et al. 2008. ATP release through connexin hemichannels and gap junction transfer of second messengers propagate $\mathrm{Ca}^{2+}$ signals across the inner ear. Proc Natl Acad Sci 105: 18770-18775.

* Ashmore J. 2018. Outer hair cells in electromotility. Cold Spring Harb Perspect Med doi: 10.1101/cshperspect. a033522.

Ashmore JF, Ohmori H. 1990. Control of intracellular calcium by ATP in isolated outer hair cells of the guinea-pig cochlea. J Physiol 428: 109-131.

Bagger-Sjoback D, Engstrom B, Steinholtz L, Hillerdal M. 1987. Freeze fracturing of the human stria vascularis. Acta Otolaryngol 103: 64-72.

Barrio LC, Suchyna T, Bargiello T, Xu LX, Roginski RS, Bennett MV, Nicholson BJ. 1991. Gap junctions formed by connexins 26 and 32 alone and in combination are differently affected by applied voltage. Proc Natl Acad Sci 88: 8410-8414.

Bedner P, Niessen H, Odermatt B, Kretz M, Willecke K, Harz H. 2006. Selective permeability of different connexin channels to the second messenger cyclic AMP. J Biol Chem 281: 6673-6681.

Beltramello M, Piazza V, Bukauskas FF, Pozzan T, Mammano F. 2005. Impaired permeability to $\operatorname{Ins}(1,4,5) \mathrm{P}_{3}$ in a mutant connexin underlies recessive hereditary deafness. Nat Cell Biol 7: 63-69.

Bennett BC, Purdy MD, Baker KA, Acharya C, McIntire WE, Stevens RC, Zhang Q, Harris AL, Abagyan R, Yeager M. 2016. An electrostatic mechanism for $\mathrm{Ca}^{2+}$-mediated regulation of gap junction channels. Nat Commun 7: 8770.

Berger AC, Kelly JJ, Lajoie P, Shao Q, Laird DW. 2014. Mutations in Cx30 that are linked to skin disease and nonsyndromic hearing loss exhibit several distinct cellular pathologies. J Cell Sci 127: 1751-1764.

Berridge MJ. 2009. Inositol trisphosphate and calcium signalling mechanisms. Biochim Biophys Acta 1793: 933940.
Beurg M, Evans MG, Hackney CM, Fettiplace R. 2006. A large-conductance calcium-selective mechanotransducer channel in mammalian cochlear hair cells. J Neurosci 26: 10992-11000.

Beutner D, Moser T. 2001. The presynaptic function of mouse cochlear inner hair cells during development of hearing. J Neurosci 21: 4593-4599.

Beyer EC, Berthoud VM. 2018. Gap junction gene and protein families: Connexins, innexins, and pannexins. Biochim Biophys Acta 1860: 5-8.

Bosen F, Schutz M, Beinhauer A, Strenzke N, Franz T, Willecke K. 2014. The Clouston syndrome mutation connexin30 A88V leads to hyperproliferation of sebaceous glands and hearing impairments in mice. FEBS Lett 588: 1795-1801.

Boulay A, del Castillo FJ, Giraudet F, Hamard G, Giaume C, Petit C, Avan P, Cohen-Salmon M. 2013. Hearing is normal without connexin30. J Neurosci 33: 430-434.

Brightman MW, Reese TS. 1969. Junctions between intimately apposed cell membranes in the vertebrate brain. J Cell Biol 40: 648-677.

Bruzzone S, Guida L, Zocchi E, Franco L, De Flora A. 2001. Connexin 43 hemi channels mediate $\mathrm{Ca}^{2+}$-regulated transmembrane $\mathrm{NAD}^{+}$fluxes in intact cells. FASEB $J$ 15: $10-12$.

Bryant J, Goodyear RJ, Richardson GP. 2002. Sensory organ development in the inner ear: Molecular and cellular mechanisms. Br Med Bull 63: 39-57.

Bukauskas FF, Jordan K, Bukauskiene A, Bennett MV, Lampe PD, Laird DW, Verselis VK. 2000. Clustering of connexin 43-enhanced green fluorescent protein gap junction channels and functional coupling in living cells. Proc Natl Acad Sci 97: 2556-2561.

Bulankina AV, Moser T. 2012. Neural circuit development in the mammalian cochlea. Physiology 27: 100-112.

Buniello A, Montanaro D, Volinia S, Gasparini P, Marigo V. 2004. An expression atlas of connexin genes in the mouse. Genomics 83: 812-820.

Butterweck A, Elfgang C, Willecke K, Traub O. 1994. Differential expression of the gap junction proteins connexin 45, $-43,-40,-31$, and -26 in mouse skin. Eur J Cell Biol 65: 152-163.

Carlisle L, Steel K, Forge A. 1990. Endocochlear potential generation is associated with intercellular communication in the stria vascularis: Structural analysis in the viable dominant spotting mouse mutant. Cell Tissue Res 262: 329-337.

Carrer A, Leparulo A, Crispino G, Ciubotaru CD, Marin O, Zonta F, Bortolozzi M. 2018. Cx32 hemichannel opening by cytosolic $\mathrm{Ca}^{2+}$ is inhibited by the R220X mutation that causes Charcot-Marie-Tooth disease. Hum Mol Genet 27: 80-94.

Caspar DL, Goodenough DA, Makowski L, Phillips WC. 1977. Gap junction structures. I: Correlated electron microscopy and X-ray diffraction. J Cell Biol 74: 605-628.

Ceriani F, Mammano F. 2013. A rapid and sensitive assay of intercellular coupling by voltage imaging of gap junction networks. Cell Commun Signal 11: 78.

Ceriani F, Ciubotaru CD, Bortolozzi M, Mammano F. 2016a. Design and construction of a cost-effective spinning disk 


\section{F. Mammano}

system for live imaging of inner ear tissue. Methods Mol Biol 1427: 223-241.

Ceriani F, Pozzan T, Mammano F. 2016b. Critical role of ATP-induced ATP release for $\mathrm{Ca}^{2+}$ signaling in nonsensory cell networks of the developing cochlea. Proc Natl Acad Sci 113: E7194-E7201.

Chang Q, Tang W, Ahmad S, Zhou B, Lin X. 2008. Gap junction mediated intercellular metabolite transfer in the cochlea is compromised in connexin 30 null mice. PLOS ONE 3: e4088.

Cherian PP, Siller-Jackson AJ, Gu S, Wang X, Bonewald LF, Sprague E, Jiang JX. 2005. Mechanical strain opens connexin 43 hemichannels in osteocytes: A novel mechanism for the release of prostaglandin. Mol Biol Cell 16: 31003106.

Clause A, Kim G, Sonntag M, Weisz CJ, Vetter DE, Rubsamen R, Kandler K. 2014. The precise temporal pattern of prehearing spontaneous activity is necessary for tonotopic map refinement. Neuron 82: 822-835.

Cody AR, Russell IJ. 1987. The response of hair cells in the basal turn of the guinea-pig cochlea to tones. J Physiol 383: 551-569.

Cohen-Salmon M, Ott T, Michel V, Hardelin JP, Perfettini I, Eybalin M, Wu T, Marcus DC, Wangemann P, Willecke $\mathrm{K}$, et al. 2002. Targeted ablation of connexin26 in the inner ear epithelial gap junction network causes hearing impairment and cell death. Curr Biol 12: 1106-1111.

Cohen-Salmon M, Maxeiner S, Kruger O, Theis M, Willecke K, Petit C. 2004. Expression of the connexin43- and connexin45-encoding genes in the developing and mature mouse inner ear. Cell Tissue Res 316: 15-22.

Cohen-Salmon M, Regnault B, Cayet N, Caille D, Demuth K, Hardelin JP, Janel N, Meda P, Petit C. 2007. Connexin30 deficiency causes instrastrial fluid-blood barrier disruption within the cochlear stria vascularis. Proc Natl Acad Sci 104: 6229-6234.

Cox BC, Liu Z, Lagarde MM, Zuo J. 2012. Conditional gene expression in the mouse inner ear using Cre-loxP. J Assoc Res Otolaryngol 13: 295-322.

Crispino G, Di Pasquale G, Scimemi P, Rodriguez L, Galindo Ramirez F, De Siati RD, Santarelli RM, Arslan E, Bortolozzi M, Chiorini JA, et al. 2011. BAAV mediated GJB2 gene transfer restores gap junction coupling in cochlear organotypic cultures from deaf Cx26 ${ }^{\text {Sox10Cre }}$ mice. PLoS ONE 6: e23279.

Crispino G, Galindo Ramirez F, Campioni M, Zorzi V, Praetorius M, Di Pasquale G, Chiorini JA, Mammano F. 2017. In vivo genetic manipulation of inner ear connexin expression by bovine adeno-associated viral vectors. Sci Rep 7: 6567.

D'Adamo P, Guerci VI, Fabretto A, Faletra F, Grasso DL, Ronfani L, Montico M, Morgutti M, Guastalla P, Gasparini P. 2009. Does epidermal thickening explain GJB2 high carrier frequency and heterozygote advantage? Eur J Hum Genet 17: 284-286.

Dallos P. 1986. Neurobiology of cochlear inner and outer hair cells: Intracellular recordings. Hear Res 22: 185-198.

Dallos P, Santos-Sacchi J, Flock A. 1982. Intracellular recordings from cochlear outer hair cells. Science 218: 582-584.

D’Andrea P, Veronesi V, Bicego M, Melchionda S, Zelante L, Di Iorio E, Bruzzone R, Gasparini P. 2002. Hearing loss:
Frequency and functional studies of the most common connexin26 alleles. Biochem Biophys Res Commun 296: 685-691.

del Castillo FJ, del Castillo I. 2017. DFNB1 non-syndromic hearing impairment: Diversity of mutations and associated phenotypes. Front Mol Neurosci 10: 428.

del Castillo I, Villamar M, Moreno-Pelayo MA, del Castillo FJ, Alvarez A, Telleria D, Menendez I, Moreno F. 2002. A deletion involving the connexin 30 gene in nonsyndromic hearing impairment. N Engl J Med 346: 243-249.

del Castillo I, Moreno-Pelayo MA, del Castillo FJ, Brownstein Z, Marlin S, Adina Q, Cockburn DJ, Pandya A, Siemering KR, Chamberlin GP, et al. 2003. Prevalence and evolutionary origins of the del(GJB6-D13S1830) mutation in the DFNB1 locus in hearing-impaired subjects: A multicenter study. Am J Hum Genet 73: 1452-1458.

del Castillo FJ, Rodriguez-Ballesteros M, Alvarez A, Hutchin T, Leonardi E, de Oliveira CA, Azaiez H, Brownstein Z, Avenarius MR, Marlin S, et al. 2005. A novel deletion involving the connexin-30 gene, $\operatorname{del}($ GJB6-d13s1854), found in trans with mutations in the GJB2 gene (connexin-26) in subjects with DFNB1 non-syndromic hearing impairment. J Med Genet 42: 588-594.

Denoyelle F, Weil D, Maw MA, Wilcox SA, Lench NJ, AllenPowell DR, Osborn AH, Dahl HH, Middleton A, Houseman MJ, et al. 1997. Prelingual deafness: High prevalence of a 30 delG mutation in the connexin 26 gene. Hum Mol Genet 6: 2173-2177.

Denoyelle F, Lina-Granade G, Plauchu H, Bruzzone R, Chaib H, Levi-Acobas F, Weil D, Petit C. 1998. Connexin 26 gene linked to a dominant deafness. Nature 393: 319320.

De Vuyst E, Decrock E, Cabooter L, Dubyak GR, Naus CC, Evans WH, Leybaert L. 2006. Intracellular calcium changes trigger connexin 32 hemichannel opening. EMBO J 25: 34-44.

De Vuyst E, Wang N, Decrock E, De Bock M, Vinken M, Van Moorhem M, Lai C, Culot M, Rogiers V, Cecchelli R, et al. 2009. $\mathrm{Ca}^{2+}$ regulation of connexin 43 hemichannels in C6 glioma and glial cells. Cell Calcium 46: 176-187.

Dewey MM, Barr L. 1962. Intercellular connection between smooth muscle cells: The nexus. Science 137: 670-672.

D’Hondt C, Iyyathurai J, Vinken M, Rogiers V, Leybaert L, Himpens B, Bultynck G. 2013. Regulation of connexinand pannexin-based channels by post-translational modifications. Biol Cell 105: 373-398.

Di WL, Rugg EL, Leigh IM, Kelsell DP. 2001. Multiple epidermal connexins are expressed in different keratinocyte subpopulations including connexin 31. J Invest Dermatol 117: 958-964.

Di WL, Monypenny J, Common JE, Kennedy CT, Holland KA, Leigh IM, Rugg EL, Zicha D, Kelsell DP. 2002. Defective trafficking and cell death is characteristic of skin disease-associated connexin 31 mutations. Hum Mol Genet 11: 2005-2014.

Di Paolo G, Moskowitz HS, Gipson K, Wenk MR, Voronov S, Obayashi M, Flavell R, Fitzsimonds RM, Ryan TA, De Camilli P. 2004. Impaired PtdIns $(4,5) \mathrm{P}_{2}$ synthesis in nerve terminals produces defects in synaptic vesicle trafficking. Nature 431: 415-422.

Di Pasquale G, Chiorini JA. 2006. AAV transcytosis through barrier epithelia and endothelium. Mol Ther 13: 506-516. 
Di Pasquale G, Rzadzinska A, Schneider ME, Bossis I, Chiorini JA, Kachar B. 2005. A novel bovine virus efficiently transduces inner ear neuroepithelial cells. Mol Ther 11: 849-855.

Dulon D, Mollard P, Aran JM. 1991. Extracellular ATP elevates cytosolic $\mathrm{Ca}^{2+}$ in cochlear inner hair cells. NeuroReport 2: 69-72.

Dulon D, Moataz R, Mollard P. 1993. Characterization of $\mathrm{Ca}^{2+}$ signals generated by extracellular nucleotides in supporting cells of the organ of Corti. Cell Calcium 14: 245254.

Easton JA, Donnelly S, Kamps MA, Steijlen PM, Martin PE, Tadini G, Janssens R, Happle R, van Geel M, van Steensel MA. 2012. Porokeratotic eccrine nevus may be caused by somatic connexin26 mutations. J Invest Dermatol 132: 2184-2191.

Echteler SM, Magardino T, Rontal M. 2005. Spatiotemporal patterns of neuronal programmed cell death during postnatal development of the gerbil cochlea. Brain Res Dev Brain Res 157: 192-200.

Eggston AA, Wolff D. 1947. Embryology of the ear. In Histopathology of the ear, nose, and throat (ed. Eggston AA, Wolff D), pp. 37-64. Williams and Wilkins, Baltimore.

Esseltine JL, Laird DW. 2016. Next-generation connexin and pannexin cell biology. Trends Cell Biol 26: 944-955.

Essenfelder GM, Bruzzone R, Lamartine J, Charollais A, Blanchet-Bardon C, Barbe MT, Meda P, Waksman G. 2004. Connexin 30 mutations responsible for hidrotic ectodermal dysplasia cause abnormal hemichannel activity. Hum Mol Genet 13: 1703-1714.

Estivill X, Fortina P, Surrey S, Rabionet R, Melchionda S, D’Agruma L, Mansfield E, Rappaport E, Govea N, Mila M, et al. 1998. Connexin-26 mutations in sporadic and inherited sensorineural deafness. Lancet 351: 394-398.

Ferrary E, Sterkers O, Saumon G, Tran Ba Huy P, Amiel C. 1987. Facilitated transfer of glucose from blood into perilymph in the rat cochlea. Am J Physiol 253: F59-F65.

Fetoni AR, Zorzi V, Paciello F, Ziraldo G, Peres C, Raspa M, Scavizzi F, Salvatore AM, Crispino G, Tognola G, et al. 2018. Cx26 partial loss causes accelerated presbycusis by redox imbalance and dysregulation of $\mathrm{Nfr} 2$ pathway. Redox Biol doi: 10.1016/j.redox.2018.08.002.

Firbas W, Gruber H, Wicke W. 1981. The blood vessels of the limbus spiralis. Arch Otorhinolaryngol 232: 131-137.

Forge A. 1984. Gap junctions in the stria vascularis and effects of ethacrynic acid. Hear Res 13: 189-200.

Forge A, Becker D, Casalotti S, Edwards J, Evans WH, Lench N, Souter M. 1999. Gap junctions and connexin expression in the inner ear. Novartis Found Symp 219: 151-136.

Forge A, Becker D, Casalotti S, Edwards J, Marziano N, Nevill G. 2003a. Gap junctions in the inner ear: Comparison of distribution patterns in different vertebrates and assessement of connexin composition in mammals. $J$ Comp Neurol 467: 207-231.

Forge A, Marziano NK, Casalotti SO, Becker DL, Jagger D. 2003b. The inner ear contains heteromeric channels composed of cx26 and cx30 and deafness-related mutations in cx26 have a dominant negative effect on cx30. Cell Commun Adhes 10: 341-346.

Franke K. 1978. Freeze fracture aspects of the spiral limbus. Arch Otorhinolaryngol 221: 157-162.
Franke K. 1979. Fine structure of the tissue lining the cochlear perilymphatic space against the bony labyrinthine capsule. Arch Otorhinolaryngol 222: 161-167.

Frolenkov GI. 2006. Regulation of electromotility in the cochlear outer hair cell. J Physiol 576: 43-48.

Frolenkov GI, Mammano F, Kachar B. 2003. Regulation of outer hair cell cytoskeletal stiffness by intracellular $\mathrm{Ca}^{2+}$ : Underlying mechanism and implications for cochlear mechanics. Cell Calcium 33: 185-195.

Fujimoto K. 1995. Freeze-fracture replica electron microscopy combined with SDS digestion for cytochemical labeling of integral membrane proteins. Application to the immunogold labeling of intercellular junctional complexes. J Cell Sci 108: 3443-3449.

Gabriel HD, Jung D, Butzler C, Temme A, Traub O, Winterhager E, Willecke K. 1998. Transplacental uptake of glucose is decreased in embryonic lethal connexin26-deficient mice. J Cell Biol 140: 1453-1461.

Gale JE, Piazza V, Ciubotaru CD, Mammano F. 2004. A mechanism for sensing noise damage in the inner ear. Curr Biol 14: 526-529.

Garcia IE, Bosen F, Mujica P, Pupo A, Flores-Munoz C, Jara O, Gonzalez C, Willecke K, Martinez AD. 2016. From hyperactive connexin 26 hemichannels to impairments in epidermal calcium gradient and permeability barrier in the keratitis-ichthyosis-deafness syndrome. J Invest Dermatol 136: 574-583.

Glowatzki E, Fuchs PA. 2000. Cholinergic synaptic inhibition of inner hair cells in the neonatal mammalian cochlea. Science 288: 2366-2368.

Goldberg GS, Lampe PD, Nicholson BJ. 1999. Selective transfer of endogenous metabolites through gap junctions composed of different connexins. Nat Cell Biol 1: 457459.

Goldberg GS, Moreno AP, Lampe PD. 2002. Gap junctions between cells expressing connexin 43 or 32 show inverse permselectivity to adenosine and ATP. J Biol Chem 277: 36725-36730.

Goliger JA, Paul DL. 1994. Expression of gap junction proteins $\mathrm{Cx} 26, \mathrm{Cx} 31.1, \mathrm{Cx} 37$, and $\mathrm{Cx} 43$ in developing and mature rat epidermis. Dev Dyn 200: 1-13.

Gomez-Hernandez JM, Miguel MC, Larrosa B, Gonzalez D, Barrio LC. 2003. Molecular basis of calcium regulation in connexin-32 hemichannels. Proc Natl Acad Sci 100: 16030-16035.

Goodenough DA. 1974. Bulk isolation of mouse hepatocyte gap junctions. Characterization of the principal protein, connexin. J Cell Biol 61: 557-563.

Gopalarao D, Kimberling WJ, Jesteadt W, Kelley PM, Beauchaine KL, Cohn ES. 2008. Is hearing loss due to mutations in the connexin 26 gene progressive? Int J Audiol 47: $11-20$.

Grifa A, Wagner CA, D’Ambrosio L, Melchionda S, Bernardi F, Lopez-Bigas N, Rabionet R, Arbones M, Monica MD, Estivill X, et al. 1999. Mutations in GJB6 cause nonsyndromic autosomal dominant deafness at DFNA3 locus. Nat Genet 23: 16-18.

Gulley RL, Reese TS. 1976. Intercellular junctions in the reticular lamina of the organ of Corti. J Neurocytol 5: 479-507. 


\section{F. Mammano}

Gustafsson MG, Shao L, Carlton PM, Wang CJ, Golubovskaya IN, Cande WZ, Agard DA, Sedat JW. 2008. Threedimensional resolution doubling in wide-field fluorescence microscopy by structured illumination. Biophys $J$ 94: 4957-4970.

Hama K, Saito K. 1977. Gap junctions between the supporting cells in some acoustico-vestibular receptors. J Neurocytol 6: 1-12.

Hanani M. 2012. Lucifer yellow-An angel rather than the devil. J Cell Mol Med 16: 22-31.

He LQ, Liu Y, Cai F, Tan ZP, Pan Q, Liang DS, Long ZG, Wu LQ, Huang LQ, Dai HP, et al. 2005. Intracellular distribution, assembly and effect of disease-associated connexin 31 mutants in HeLa cells. Acta Biochim Biophys Sin (Shanghai) 37: 547-554.

Hernandez VH, Bortolozzi M, Pertegato V, Beltramello M, Giarin M, Zaccolo M, Pantano S, Mammano F. 2007 Unitary permeability of gap junction channels to second messengers measured by FRET microscopy. Nat Methods 4: 353-358.

Hinojosa R. 1977. A note on development of Corti's organ Acta Otolaryngol 84: 238-251.

* Holt J, Corey D. 2018. TMC channels in cochlear hair cells: Roles in hearing and deafness. Cold Spring Harb Perspect Med doi: 10.1101/cshperspect.a033506.

Housley GD, Ashmore JF. 1992. Ionic currents of outer hair cells isolated from the guinea-pig cochlea. J Physiol 448: 73-98.

Housley GD, Greenwood D, Ashmore JF. 1992. Localization of cholinergic and purinergic receptors on outer hair cells isolated from the guinea-pig cochlea. Proc Biol Sci 249: 265-273.

Housley GD, Jagger DJ, Greenwood D, Raybould NP, Salih SG, Jarlebark LE, Vlajkovic SM, Kanjhan R, Nikolic P, Munoz DJ, et al. 2002. Purinergic regulation of sound transduction and auditory neurotransmission. Audiol Neurootol 7: 55-61.

Housley GD, Bringmann A, Reichenbach A. 2009. Purinergic signaling in special senses. Trends Neurosci 32: 128141.

Housley GD, Morton-Jones R, Vlajkovic SM, Telang RS, Paramananthasivam V, Tadros SF, Wong AC, Froud KE, Cederholm JM, Sivakumaran Y, et al. 2013. ATPgated ion channels mediate adaptation to elevated sound levels. Proc Natl Acad Sci 110: 7494-7499.

Hu Z, Riquelme MA, Wang B, Bugay V, Brenner R, Gu S, Jiang JX. 2018. Cataract-associated connexin 46 mutation alters its interaction with calmodulin and function of hemichannels. J Biol Chem 293: 2573-2585.

Huang YJ, Maruyama Y, Dvoryanchikov G, Pereira E, Chaudhari N, Roper SD. 2007. The role of pannexin 1 hemichannels in ATP release and cell-cell communication in mouse taste buds. Proc Natl Acad Sci 104: 64366441.

Huckstepp RT, Eason R, Sachdev A, Dale N. 2010. $\mathrm{CO}_{2-}$ dependent opening of connexin 26 and related $\beta$ connexins. J Physiol 588: 3921-3931.

Imamura $\mathrm{H}$, Nhat KP, Togawa $\mathrm{H}$, Saito K, Iino R, KatoYamada Y, Nagai T, Noji H. 2009. Visualization of ATP levels inside single living cells with fluorescence reso- nance energy transfer-based genetically encoded indicators. Proc Natl Acad Sci 106: 15651-15656.

Iurato S, Franke K, Luciano L, Wermbter G, Pannese E, Reale E. 1976a. Fracture faces of the junctional complexes in the reticular membrane of the organ of Corti. Acta Otolaryngol 81: 36-47.

Iurato S, Franke K, Luciano L, Wermbter G, Pannese E, Reale E. . 1976b. Intercellular junctions in the organ of Corti as revealed by freeze fracturing. Acta Otolaryngol 82: 57-69.

Jagger DJ, Forge A. 2006. Compartmentalized and signalselective gap junctional coupling in the hearing cochlea. J Neurosci 26: 1260-1268.

Jagger DJ, Forge A. 2013. The enigmatic root cell-Emerging roles contributing to fluid homeostasis within the cochlear outer sulcus. Hear Res 303: 1-11.

Jagger DJ, Forge A. 2015. Connexins and gap junctions in the inner ear-It's not just about $\mathrm{K}^{+}$recycling. Cell Tissue Res 360: 633-644.

Jahnke K. 1975. Die feinstruktur gefriergeätzter zellmembran-haftstellen der Stria vascularis [The fine structure of freeze-etched cell membrane adhesions of the Stria vascularis]. Anat Embryol 147: 189-201.

Jensen-Smith HC, Hallworth R, Nichols MG. 2012. Gentamicin rapidly inhibits mitochondrial metabolism in highfrequency cochlear outer hair cells. PLoS ONE 7: e38471.

Johnson SL, Beurg M, Marcotti W, Fettiplace R. 2011. Prestin-driven cochlear amplification is not limited by the outer hair cell membrane time constant. Neuron 70: 1143-1154.

Johnson SL, Kuhn S, Franz C, Ingham N, Furness DN, Knipper M, Steel KP, Adelman JP, Holley MC, Marcotti W. 2013a. Presynaptic maturation in auditory hair cells requires a critical period of sensory-independent spiking activity. Proc Natl Acad Sci 110: 8720-8725.

Johnson SL, Wedemeyer C, Vetter DE, Adachi R, Holley MC, Elgoyhen AB, Marcotti W. 2013b. Cholinergic efferent synaptic transmission regulates the maturation of auditory hair cell ribbon synapses. Open Biol 3: 130163.

Johnson SL, Ceriani F, Houston O, Polishchuk R, Polishchuk E, Crispino G, Zorzi V, Mammano F, Marcotti W. 2017. Connexin-mediated signaling in nonsensory cells is crucial for the development of sensory inner hair cells in the mouse cochlea. J Neurosci 37: 258-268.

Kadamur G, Ross EM. 2013. Mammalian phospholipase C. Annu Rev Physiol 75: 127-154.

Kamermans M, Fahrenfort I, Schultz K, Janssen-Bienhold U, Sjoerdsma T, Weiler R. 2001. Hemichannel-mediated inhibition in the outer retina. Science 292: 1178-1180.

Kanaporis G, Mese G, Valiuniene L, White TW, Brink PR, Valiunas V. 2008. Gap junction channels exhibit connexin-specific permeability to cyclic nucleotides. J Gen Physiol 131: 293-305.

Karagiannis A, Sylantyev S, Hadjihambi A, Hosford PS, Kasparov S, Gourine AV. 2016. Hemichannel-mediated release of lactate. J Cereb Blood Flow Metab 36: 1202-1211.

Kelley MW. 2007. Cellular commitment and differentiation in the organ of Corti. Int J Dev Biol 51: 571-583.

Kelly JJ, Forge A, Jagger DJ. 2011. Development of gap junctional intercellular communication within the lateral wall of the rat cochlea. Neuroscience 180: 360-369. 
Inner Ear Connexin Channels

Kelsell DP, Dunlop J, Stevens HP, Lench NJ, Liang JN, Parry G, Mueller RF, Leigh IM. 1997. Connexin 26 mutations in hereditary non-syndromic sensorineural deafness. Nature 387: $80-83$.

Kenna MA, Feldman HA, Neault MW, Frangulov A, Wu BL, Fligor B, Rehm HL. 2010. Audiologic phenotype and progression in GJB2 (connexin 26) hearing loss. Arch Otolaryngol Head Neck Surg 136: 81-87.

Kikuchi T, Kimura RS, Paul DL, Adams JC. 1995. Gap junctions in the rat cochlea: Immunohistochemical and ultrastructural analysis. Anat Embryol (Berl) 191: 101-118.

Kikuchi T, Adams JC, Miyabe Y, So E, Kobayashi T. 2000a. Potassium ion recycling pathway via gap junction systems in the mammalian cochlea and its interruption in hereditary nonsyndromic deafness. Med Electron Microsc 33: 51-56.

Kikuchi T, Kimura RS, Paul DL, Takasaka T, Adams JC. 2000b. Gap junction systems in the mammalian cochlea. Brain Res Brain Res Rev 32: 163-166.

Kim DY, Kam Y, Koo SK, Joe CO. 1999. Gating connexin 43 channels reconstituted in lipid vesicles by mitogen-activated protein kinase phosphorylation. J Biol Chem 274: 5581-5587.

Kirikae I, Nomura Y, Hiraide F. 1969. The capillary in the human cochlea. Acta Otolaryngol 67: 1-8.

Kros CJ, Ruppersberg JP, Rusch A. 1998. Expression of a potassium current in inner hair cells during development of hearing in mice. Nature 394: 281-284.

Kumar NM, Gilula NB. 1996. The gap junction communication channel. Cell 84: 381-388.

Lagostena L, Mammano F. 2001. Intracellular calcium dynamics and membrane conductance changes evoked by Deiters' cell purinoceptor activation in the organ of Corti. Cell Calcium 29: 191-198.

Lagostena L, Ashmore JF, Kachar B, Mammano F. 2001. Purinergic control of intercellular communication between Hensen's cells of the guinea-pig cochlea. J Physiol 531: 693-706.

Lamartine J, Munhoz Essenfelder G, Kibar Z, Lanneluc I, Callouet E, Laoudj D, Lemaitre G, Hand C, Hayflick SJ, Zonana J, et al. 2000. Mutations in GJB6 cause hidrotic ectodermal dysplasia. Nat Genet 26: 142-144.

Lautermann J, ten Cate WJ, Altenhoff P, Grummer R, Traub O, Frank H, Jahnke K, Winterhager E. 1998. Expression of the gap-junction connexins 26 and 30 in the rat cochlea. Cell Tissue Res 294: 415-420.

Lautermann J, Frank HG, Jahnke K, Traub O, Winterhager E. 1999. Developmental expression patterns of connexin26 and -30 in the rat cochlea. Dev Genet 25: 306311.

Lazic T, Li Q, Frank M, Uitto J, Zhou LH. 2012. Extending the phenotypic spectrum of keratitis-ichthyosis-deafness syndrome: Report of a patient with GJB2 (G12R) connexin 26 mutation and unusual clinical findings. Pediatric Dermatol 29: 349-357.

Lee JR, White TW. 2009. Connexin-26 mutations in deafness and skin disease. Exp Rev Mol Med 11: e35.

Leist M, Single B, Castoldi AF, Kuhnle S, Nicotera P. 1997. Intracellular adenosine triphosphate (ATP) concentration: A switch in the decision between apoptosis and necrosis. J Exp Med 185: 1481-1486.
Lerer I, Sagi M, Ben-Neriah Z, Wang T, Levi H, Abeliovich D. 2001. A deletion mutation in GJB6 cooperating with a GJB2 mutation in trans in non-syndromic deafness: A novel founder mutation in Ashkenazi Jews. Hum Mutat 18: 460 .

Levesque SA, Lavoie EG, Lecka J, Bigonnesse F, Sevigny J. 2007. Specificity of the ecto-ATPase inhibitor ARL 67156 on human and mouse ectonucleotidases. Br J Pharmacol 152: $141-150$.

Leybaert L, Braet K, Vandamme W, Cabooter L, Martin PE, Evans WH. 2003. Connexin channels, connexin mimetic peptides and ATP release. Cell Commun Adhes 10: 251257.

Leybaert L, Lampe PD, Dhein S, Kwak BR, Ferdinandy P, Beyer EC, Laird DW, Naus CC, Green CR, Schulz R. 2017. Connexins in cardiovascular and neurovascular health and disease: Pharmacological implications. Pharmacol Rev 69: 396-478.

Li H, Liu TF, Lazrak A, Peracchia C, Goldberg GS, Lampe PD, Johnson RG. 1996. Properties and regulation of gap junctional hemichannels in the plasma membranes of cultured cells. J Cell Biol 134: 1019-1030.

Lilly E, Sellitto C, Milstone LM, White TW. 2016. Connexin channels in congenital skin disorders. Semin Cell Dev Biol 50: 4-12.

Lim DJ, Anniko M. 1985. Developmental morphology of the mouse inner ear. A scanning electron microscopic observation. Acta Otolaryngol Suppl 422: 1-69.

Lim D, Rueda J. 1992. Structural development of the cochlea. In Development of auditory and vestibular systems-2, 1 st ed. (ed. Romand R), pp. 33-58. Elsevier, New York.

Liu YP, Zhao HB. 2008. Cellular characterization of connexin 26 and connexin 30 expression in the cochlear lateral wall. Cell Tissue Res 333: 395-403.

Liu XZ, Yuan Y, Yan D, Ding EH, Ouyang XM, Fei Y, Tang W, Yuan H, Chang Q, Du LL, et al. 2009. Digenic inheritance of non-syndromic deafness caused by mutations at the gap junction proteins $\mathrm{Cx} 26$ and $\mathrm{Cx} 31$. Hum Genet 125: 53-62.

Liu W, Edin F, Blom H, Magnusson P, Schrott-Fischer A, Glueckert R, Santi PA, Li H, Laurell G, Rask-Andersen H. 2016. Super-resolution structured illumination fluorescence microscopy of the lateral wall of the cochlea: The connexin $26 / 30$ proteins are separately expressed in man. Cell Tissue Res 365: 13-27.

Liu W, Li H, Edin F, Brannstrom J, Glueckert R, SchrottFischer A, Molnar M, Pacholsky D, Pfaller K, Rask-Andersen H. 2017. Molecular composition and distribution of gap junctions in the sensory epithelium of the human cochlea-a super-resolution structured illumination microscopy (SR-SIM) study. Ups J Med Sci 122: 160-170.

Loonstra A, Vooijs M, Beverloo HB, Allak BA, van Drunen E, Kanaar R, Berns A, Jonkers J. 2001. Growth inhibition and DNA damage induced by Cre recombinase in mammalian cells. Proc Natl Acad Sci 98: 9209-9214.

Lurtz MM, Louis CF. 2007. Intracellular calcium regulation of connexin43. Am J Physiol Cell Physiol 293: C1806C1813.

Lynn BD, Tress O, May D, Willecke K, Nagy JI. 2011. Ablation of connexin 30 in transgenic mice alters expression patterns of connexin 26 and connexin 32 in glial cells and leptomeninges. Eur J Neurosci 34: 1783-1793. 


\section{F. Mammano}

Maeda S, Nakagawa S, Suga M, Yamashita E, Oshima A, Fujiyoshi Y, Tsukihara T. 2009. Structure of the connexin 26 gap junction channel at $3.5 \AA$ resolution. Nature 458: 597-602

Maestrini E, Korge BP, Ocana-Sierra J, Calzolari E, Cambiaghi S, Scudder PM, Hovnanian A, Monaco AP, Munro CS. 1999. A missense mutation in connexin26, D66H, causes mutilating keratoderma with sensorineural deafness (Vohwinkel's syndrome) in three unrelated families. Hum Mol Genet 8: 1237-1243.

Majumder P, Crispino G, Rodriguez L, Ciubotaru CD, Anselmi F, Piazza V, Bortolozzi M, Mammano F. 2010. ATPmediated cell-cell signaling in the organ of Corti: The role of connexin channels. Purinergic Signal 6: 167-187.

Makowski L, Caspar DL, Phillips WC, Goodenough DA. 1977. Gap junction structures. II: Analysis of the X-ray diffraction data. J Cell Biol 74: 629-645.

Mammano F, Bortolozzi M. 2018. $\mathrm{Ca}^{2+}$ signaling, apoptosis and autophagy in the developing cochlea: Milestones to hearing acquisition. Cell Calcium 70: 117-126.

Mammano F, Nobili R. 1993. Biophysics of the cochlea: Linear approximation. J Acoust Soc Am 93: 3320-3332.

Mammano F, Goodfellow SJ, Fountain E. 1996. Electrophysiological properties of Hensen's cells investigated in situ. NeuroReport 7: 537-542.

Mammano F, Frolenkov GI, Lagostena L, Belyantseva IA, Kurc M, Dodane V, Colavita A, Kachar B. 1999. ATP Induced $\mathrm{Ca}^{2+}$ release in cochlear outer hair cells: Localization of an inositol triphosphate-gated $\mathrm{Ca}^{2+}$ store to the base of the sensory hair bundle. J Neurosci 19: 6918-6929.

* Marcotti W, Safieddine S. 2018. Inner hair cell afferent synapses: Molecular mechanisms. Cold Spring Harb Perspect Med doi: 10.1101/cshperspect.a033175.

Marcotti W, Johnson SL, Holley MC, Kros CJ. 2003. Developmental changes in the expression of potassium currents of embryonic, neonatal and mature mouse inner hair cells. J Physiol 548: 383-400.

Matern M, Vijayakumar S, Margulies Z, Milon B, Song Y, Elkon R, Zhang X, Jones SM, Hertzano R. 2017. Gfi1 ${ }^{\text {Cre }}$ mice have early onset progressive hearing loss and induce recombination in numerous inner ear non-hair cells. Sci Rep 7: 42079.

Meigh L, Greenhalgh SA, Rodgers TL, Cann MJ, Roper DI, Dale N. 2013. $\mathrm{CO}_{2}$ directly modulates connexin 26 by formation of carbamate bridges between subunits. eLife 2: $\mathrm{e} 01213$.

Mese G, Sellitto C, Li L, Wang HZ, Valiunas V, Richard G, Brink PR, White TW. 2011. The Cx26-G45E mutation displays increased hemichannel activity in a mouse model of the lethal form of keratitis-ichthyosis-deafness syndrome. Mol Biol Cell 22: 4776-4786.

Mhaske PV, Levit NA, Li L, Wang HZ, Lee JR, Shuja Z, Brink PR, White TW. 2013. The human Cx26-D50A and Cx26A88V mutations causing keratitis-ichthyosis-deafness syndrome display increased hemichannel activity. Am J Physiol Cell Physiol 304: C1150-C1158.

Miller EW, Lin JY, Frady EP, Steinbach PA, Kristan WB Jr, Tsien RY. 2012. Optically monitoring voltage in neurons by photo-induced electron transfer through molecular wires. Proc Natl Acad Sci 109: 2114-2119.
Minami SB, Mutai H, Nakano A, Arimoto Y, Taiji H, Morimoto N, Sakata H, Adachi N, Masuda S, Sakamoto H, et al. 2013. GJB2-associated hearing loss undetected by hearing screening of newborns. Gene 532: 41-45.

Mistrik P, Ashmore JF. 2010. Reduced electromotility of outer hair cells associated with connexin-related forms of deafness: An in silico study of a cochlear network mechanism. J Assoc Res Otolaryngol 11: 559-571.

Mistrik P, Mullaley C, Mammano F, Ashmore J. 2009. Threedimensional current flow in a large-scale model of the cochlea and the mechanism of amplification of sound. $J$ R Soc Interface 6: 279-291.

* Montcouquol M, Kelley MW. 2018. Development and patterning of the cochlea: From convergent extension to planar polarity. Cold Spring Harb Perspect Med doi: 10.1101/ cshperspect.a033266.

Moreno AP. 2005. Connexin phosphorylation as a regulatory event linked to channel gating. Biochim Biophys Acta 1711: 164-171.

Muller DJ, Hand GM, Engel A, Sosinsky GE. 2002. Conformational changes in surface structures of isolated connexin 26 gap junctions. EMBO J 21: 3598-3607.

Nadol JB Jr. 1978. Intercellular junctions in the organ of Corti. Ann Otol Rhinol Laryngol 87: 70-80.

Niessen H, Harz H, Bedner P, Kramer K, Willecke K. 2000. Selective permeability of different connexin channels to the second messenger inositol 1,4,5-trisphosphate. J Cell Sci 113: 1365-1372.

Nobili R, Mammano F. 1996. Biophysics of the cochlea. II: Stationary nonlinear phenomenology. J Acoust Soc Am 99: 2244-2255.

Oesterle EC, Dallos P. 1990. Intracellular recordings from supporting cells in the guinea pig cochlea: DC potentials. J Neurophysiol 64: 617-636.

Okamura H, Spicer SS, Schulte BA. 2001. Immunohistochemical localization of phospholipase $\mathrm{C}$ isozymes in mature and developing gerbil cochlea. Neuroscience 102: 451-459.

Ortolano S, Di Pasquale G, Crispino G, Anselmi F, Mammano F, Chiorini JA. 2008. Coordinated control of connexin 26 and connexin 30 at the regulatory and functional level in the inner ear. Proc Natl Acad Sci 105: 1877618781.

Orzan E, Murgia A. 2007. Connexin 26 deafness is not always congenital. Int J Pediatr Otorhinolaryngol 71: 501-507.

Palacios-Prado N, Sonntag S, Skeberdis VA, Willecke K, Bukauskas FF. 2009. Gating, permselectivity and pH-dependent modulation of channels formed by connexin57, a major connexin of horizontal cells in the mouse retina. J Physiol 587: 3251-3269.

Palacios-Prado N, Briggs SW, Skeberdis VA, Pranevicius M, Bennett MV, Bukauskas FF. 2010. pH-dependent modulation of voltage gating in connexin 45 homotypic and connexin45/connexin43 heterotypic gap junctions. Proc Natl Acad Sci 107: 9897-9902.

Pallares-Ruiz N, Blanchet P, Mondain M, Claustres M, Roux AF. 2002. A large deletion including most of GJB6 in recessive nonsyndromic deafness: A digenic effect? Eur $J$ Hum Genet 10: 72-76. 
Inner Ear Connexin Channels

Palmer AR, Russell IJ. 1986. Phase-locking in the cochlear nerve of the guinea-pig and its relation to the receptor potential of inner hair-cells. Hear Res 24: 1-15.

Paulauskas N, Pranevicius H, Mockus J, Bukauskas FF. 2012. Stochastic 16-state model of voltage gating of gap-junction channels enclosing fast and slow gates. Biophys $J$ 102: 2471-2480.

Pellegatti P, Falzoni S, Pinton P, Rizzuto R, Di Virgilio F. 2005. A novel recombinant plasma membrane-targeted luciferase reveals a new pathway for ATP secretion. Mol Biol Cell 16: 3659-3665.

Peracchia C. 2004. Chemical gating of gap junction channels; roles of calcium, $\mathrm{pH}$ and calmodulin. Biochim Biophys Acta 1662: 61-80.

Peracchia C, Bernardini G, Peracchia LL. 1983. Is calmodulin involved in the regulation of gap junction permeability? Pflugers Arch 399: 152-154.

Peracchia C, Sotkis A, Wang XG, Peracchia LL, Persechini A. 2000a. Calmodulin directly gates gap junction channels. J Biol Chem 275: 26220-26224.

Peracchia C, Wang XG, Peracchia LL. 2000b. Chemical gating of gap junction channels. Methods 20: 188-195.

Petit C. 2018. Hair-bundle links: Genetics as the gateway to function. Cold Spring Harb Perspect Med doi: 10.1101/ cshperspect.a033142.

Pfahnl A, Dahl G. 1999. Gating of cx46 gap junction hemichannels by calcium and voltage. Pflugers Arch 437: 345 353.

Piazza V, Ciubotaru CD, Gale JE, Mammano F. 2007. Purinergic signalling and intercellular $\mathrm{Ca}^{2+}$ wave propagation in the organ of Corti. Cell Calcium 41: 77-86.

Press E, Alaga KC, Barr K, Shao Q, Bosen F, Willecke K, Laird DW. 2017a. Disease-linked connexin26 S17F promotes volar skin abnormalities and mild wound healing defects in mice. Cell Death Dis 8: e2845.

Press ER, Shao Q, Kelly JJ, Chin K, Alaga A, Laird DW. 2017b. Induction of cell death and gain-of-function properties of connexin26 mutants predict severity of skin disorders and hearing loss. J Biol Chem 292: 9721-9732.

Rana S, Dringen R. 2007. Gap junction hemichannel-mediated release of glutathione from cultured rat astrocytes. Neurosci Lett 415: 45-48.

Rash JE, Yasumura T, Davidson KG, Furman CS, Dudek FE, Nagy JI. 2001. Identification of cells expressing Cx43, Cx30, Cx26, Cx32 and Cx36 in gap junctions of rat brain and spinal cord. Cell Commun Adhes 8: 315-320.

Reale E, Luciano L, Franke K, Pannese E, Wermbter G, Iurato S. 1975. Intercellular junctions in the vascular stria and spiral ligament. J Ultrastruct Res 53: 284-297.

Retamal MA. 2014. Connexin and Pannexin hemichannels are regulated by redox potential. Front Physiol 5: 80 .

Retamal MA, Cortes CJ, Reuss L, Bennett MV, Saez JC. 2006. $S$-nitrosylation and permeation through connexin 43 hemichannels in astrocytes: Induction by oxidant stress and reversal by reducing agents. Proc Natl Acad Sci 103: 4475-4480.

Retamal MA, Schalper KA, Shoji KF, Bennett MV, Saez JC. 2007. Opening of connexin 43 hemichannels is increased by lowering intracellular redox potential. Proc Natl Acad Sci 104: 8322-8327.
Retamal MA, Yin S, Altenberg GA, Reuss L. 2009. Modulation of Cx46 hemichannels by nitric oxide. Am J Physiol Cell Physiol 296: C1356-C1363.

Retamal MA, Reyes EP, Garcia IE, Pinto B, Martinez AD, Gonzalez C. 2015. Diseases associated with leaky hemichannels. Front Cell Neurosci 9: 267.

Revel JP, Karnovsky MJ. 1967. Hexagonal array of subunits in intercellular junctions of the mouse heart and liver. J Cell Biol 33: C7-C12.

Richard G, Smith LE, Bailey RA, Itin P, Hohl D, Epstein EH Jr, DiGiovanna JJ, Compton JG, Bale SJ. 1998a. Mutations in the human connexin gene GJB3 cause erythrokeratodermia variabilis. Nat Genet 20: 366-369.

Richard G, White TW, Smith LE, Bailey RA, Compton JG, Paul DL, Bale SJ. 1998b. Functional defects of Cx26 resulting from a heterozygous missense mutation in a family with dominant deaf-mutism and palmoplantar keratoderma. Hum Genet 103: 393-399.

Richard G, Rouan F, Willoughby CE, Brown N, Chung P, Ryynanen M, Jabs EW, Bale SJ, DiGiovanna JJ, Uitto J, et al. 2002. Missense mutations in GJB2 encoding connexin26 cause the ectodermal dysplasia keratitis-ichthyosisdeafness syndrome. Am J Hum Genet 70: 1341-1348.

Richard G, Brown N, Ishida-Yamamoto A, Krol A. 2004. Expanding the phenotypic spectrum of Cx26 disorders: Bart-Pumphrey syndrome is caused by a novel missense mutation in GJB2. J Invest Dermatol 123: 856-863.

Robertson JD. 1963. The occurrence of a subunit pattern in the unit membranes of club endings in mauthner cell synapses in goldfish brains. J Cell Biol 19: 201-221.

Rodriguez L, Simeonato E, Scimemi P, Anselmi F, Cali B, Crispino G, Ciubotaru CD, Bortolozzi M, Ramirez FG, Majumder P, et al. 2012. Reduced phosphatidylinositol 4,5-bisphosphate synthesis impairs inner ear $\mathrm{Ca}^{2+}$ signaling and high-frequency hearing acquisition. Proc Natl Acad Sci 109: 14013-14018.

Rose B, Loewenstein WR. 1975. Permeability of cell junction depends on local cytoplasmic calcium activity. Nature 254: $250-252$.

Rouach N, Koulakoff A, Abudara V, Willecke K, Giaume C. 2008. Astroglial metabolic networks sustain hippocampal synaptic transmission. Science 322: 1551-1555.

Rouan F, White TW, Brown N, Taylor AM, Lucke TW, Paul DL, Munro CS, Uitto J, Hodgins MB, Richard G. 2001. trans-dominant inhibition of connexin- 43 by mutant connexin-26: Implications for dominant connexin disorders affecting epidermal differentiation. J Cell Sci 114: 2105-2113.

Rubel EW, Fritzsch B. 2002. Auditory system development: Primary auditory neurons and their targets. Annu Rev Neurosci 25: 51-101.

Saez JC, Leybaert L. 2014. Hunting for connexin hemichannels. FEBS Lett 588: 1205-1211.

Saez JC, Retamal MA, Basilio D, Bukauskas FF, Bennett MV. 2005. Connexin-based gap junction hemichannels: Gating mechanisms. Biochim Biophys Acta 1711: 215-224.

Safieddine S, El-Amraoui A, Petit C. 2012. The auditory hair cell ribbon synapse: From assembly to function. Annu Rev Neurosci 35: 509-528. 


\section{F. Mammano}

Sakagami M, Fukazawa K, Murata J, Matsunaga T. 1993 Morphological aspects of transport of potassium ion in the marginal cell. Acta Otolaryngol Suppl 501: 63-65.

Salomon D, Masgrau E, Vischer S, Ullich S, Dupont E, Sappino P, Saurat JH, Meda P. 1994. Topography of mammalian connexins in human skin. J Invest Dermatol 103: 240-247.

Sanchez HA, Mese G, Srinivas M, White TW, Verselis VK. 2010. Differentially altered $\mathrm{Ca}^{2+}$ regulation and $\mathrm{Ca}^{2+}$ permeability in Cx26 hemichannels formed by the A40V and G45E mutations that cause keratitis ichthyosis deafness syndrome. J Gen Physiol 136: 47-62.

Sanchez HA, Villone K, Srinivas M, Verselis VK. 2013. The D50N mutation and syndromic deafness: Altered Cx26 hemichannel properties caused by effects on the pore and intersubunit interactions. J Gen Physiol 142: 3-22.

Sanchez HA, Bienkowski R, Slavi N, Srinivas M, Verselis VK 2014. Altered inhibition of $\mathrm{Cx} 26$ hemichannels by $\mathrm{pH}$ and $\mathrm{Zn}^{2+}$ in the $\mathrm{A} 40 \mathrm{~V}$ mutation associated with keratitis-ichthyosis-deafness syndrome. J Biol Chem 289: 21519-21532.

Sanchez HA, Slavi N, Srinivas M, Verselis VK. 2016. Syndromic deafness mutations at Asn 14 differentially alter the open stability of Cx26 hemichannels. J Gen Physiol 148: 25-42.

Santos-Sacchi J. 1991. Isolated supporting cells from the organ of Corti: Some whole cell electrical characteristics and estimates of gap junctional conductance. Hear Res 52: 89-98.

Santos-Sacchi J, Dallos P. 1983. Intercellular communication in the supporting cells of the organ of Corti. Hear Res 9 317-326.

Schutz M, Scimemi P, Majumder P, De Siati RD, Crispino G, Rodriguez L, Bortolozzi M, Santarelli R, Seydel A, Sonntag S, et al. 2010. The human deafness-associated connexin $30 \mathrm{~T} 5 \mathrm{M}$ mutation causes mild hearing loss and reduces biochemical coupling among cochlear non-sensory cells in knock-in mice. Hum Mol Genet 19: 47594773.

Schutz M, Auth T, Gehrt A, Bosen F, Korber I, Strenzke N, Moser T, Willecke K. 2011. The connexin26 S17F mouse mutant represents a model for the human hereditary keratitis-ichthyosis-deafness syndrome. Hum Mol Genet 20: 28-39.

Sheffield AM, Gubbels SP, Hildebrand MS, Newton SS, Chiorini JA, Di Pasquale G, Smith RJ. 2011. Viral vector tropism for supporting cells in the developing murine cochlea. Hear Res 277: 28-36.

Sher AE. 1971. The embryonic and postnatal development of the inner ear of the mouse. Acta Otolaryngol Suppl 285: 177.

Shibata SB, Di Pasquale G, Cortez SR, Chiorini JA, Raphael Y. 2009. Gene transfer using bovine adeno-associated virus in the guinea pig cochlea. Gene Ther 16: 990-997.

Shuja Z, Li L, Gupta S, Mese G, White TW. 2016. Connexin26 mutations causing palmoplantar keratoderma and deafness interact with connexin 43 , modifying gap junction and hemichannel properties. J Invest Dermatol 136: 225-235.

Simpson C, Kelsell DP, Marches O. 2013. Connexin 26 facilitates gastrointestinal bacterial infection in vitro. Cell Tissue Res 351: 107-116.
Smith CA. 1951. Capillary areas of the cochlea in the guinea pig. Laryngoscope 61: 1073-1095.

Snipas M, Rimkute L, Kraujalis T, Maciunas K, Bukauskas FF. 2017. Functional asymmetry and plasticity of electrical synapses interconnecting neurons through a 36-state model of gap junction channel gating. PLoS Comput Biol 13: e1005464.

Snoeckx RL, Huygen PL, Feldmann D, Marlin S, Denoyelle F, Waligora J, Mueller-Malesinska M, Pollak A, Ploski R, Murgia A, et al. 2005. GJB2 mutations and degree of hearing loss: A multicenter study. Am J Hum Genet 77: 945-957.

Sobkowicz HM, Rose JE, Scott GE, Slapnick SM. 1982. Ribbon synapses in the developing intact and cultured organ of Corti in the mouse. J Neurosci 2: 942-957.

Solan JL, Lampe PD. 2018. Spatio-temporal regulation of connexin 43 phosphorylation and gap junction dynamics. Biochim Biophys Acta 1860: 83-90.

Srinivas M, Verselis VK, White TW. 2018. Human diseases associated with connexin mutations. Biochim Biophys Acta 1860: 192-201.

Stewart WW. 1978. Functional connections between cells as revealed by dye-coupling with a highly fluorescent naphthalimide tracer. Cell 14: 741-759.

Stong BC, Chang Q, Ahmad S, Lin X. 2006. A novel mechanism for connexin 26 mutation linked deafness: Cell death caused by leaky gap junction hemichannels. Laryngoscope 116: 2205-2210.

Suadicani SO, Brosnan CF, Scemes E. 2006. P2X7 receptors mediate ATP release and amplification of astrocytic intercellular Ca ${ }^{2+}$ signaling. J Neurosci 26: 1378-1385.

Sugasawa M, Erostegui C, Blanchet C, Dulon D. 1996. ATP activates non-selective cation channels and calcium release in inner hair cells of the guinea-pig cochlea. J Physiol 491: 707-718.

Sun J, Ahmad S, Chen S, Tang W, Zhang Y, Chen P, Lin X. 2005. Cochlear gap junctions coassembled from Cx26 and 30 show faster intercellular $\mathrm{Ca}^{2+}$ signaling than homomeric counterparts. Am J Physiol Cell Physiol 288: C613-C623.

Sun Y, Tang W, Chang Q, Wang Y, Kong W, Lin X. 2009. Connexin30 null and conditional connexin 26 null mice display distinct pattern and time course of cellular degeneration in the cochlea. J Comp Neurol 516: 569-579.

Teubner B, Michel V, Pesch J, Lautermann J, Cohen-Salmon M, Sohl G, Jahnke K, Winterhager E, Herberhold C, Hardelin JP, et al. 2003. Connexin30 (Gjb6)-deficiency causes severe hearing impairment and lack of endocochlear potential. Hum Mol Genet 12: 13-21.

Thimm J, Mechler A, Lin H, Rhee S, Lal R. 2005. Calciumdependent open/closed conformations and interfacial energy maps of reconstituted hemichannels. J Biol Chem 280: 10646-10654.

Thomas T, Jordan K, Simek J, Shao Q, Jedeszko C, Walton P, Laird DW. 2005. Mechanisms of Cx43 and Cx26 transport to the plasma membrane and gap junction regeneration. J Cell Sci 118: 4451-4462.

Tian C, Gong Y, Yang Y, Shen W, Wang K, Liu J, Xu B, Zhao J, Zhao C. 2012. Foxg1 has an essential role in postnatal development of the dentate gyrus. J Neurosci 32: 29312949. 
Tong X, Lopez W, Ramachandran J, Ayad WA, Liu Y, LopezRodriguez A, Harris AL, Contreras JE. 2015. Glutathione release through connexin hemichannels: Implications for chemical modification of pores permeable to large molecules. J Gen Physiol 146: 245-254.

Tritsch NX, Yi E, Gale JE, Glowatzki E, Bergles DE. 2007 The origin of spontaneous activity in the developing auditory system. Nature 450: 50-55.

Tritsch NX, Rodriguez-Contreras A, Crins TT, Wang HC, Borst JG, Bergles DE. 2010. Calcium action potentials in hair cells pattern auditory neuron activity before hearing onset. Nat Neurosci 13: 1050-1052.

Valiunas V, Polosina YY, Miller H, Potapova IA, Valiuniene L, Doronin S, Mathias RT, Robinson RB, Rosen MR, Cohen IS, et al. 2005. Connexin-specific cell-to-cell transfer of short interfering RNA by gap junctions. J Physiol 568: 459-468.

van Geel M, van Steensel MA, Kuster W, Hennies HC, Happle R, Steijlen PM, Konig A. 2002. HID and KID syndromes are associated with the same connexin 26 mutation. Br J Dermatol 146: 938-942.

Verselis VK, Srinivas M. 2008. Divalent cations regulate connexin hemichannels by modulating intrinsic voltage-dependent gating. J Gen Physiol 132: 315-327.

Verselis VK, Srinivas M. 2013. Connexin channel modulators and their mechanisms of action. Neuropharmacology 75: 517-524.

Verselis VK, Ginter CS, Bargiello TA. 1994. Opposite voltage gating polarities of two closely related connexins. Nature 368: $348-351$.

Verselis VK, Trexler EB, Bukauskas FF. 2000. Connexin hemichannels and cell-cell channels: Comparison of properties. Braz J Med Biol Res 33: 379-389.

Vlajkovic SM, Housley GD, Munoz DJ, Robson SC, Sevigny J, Wang CJ, Thorne PR. 2004. Noise exposure induces upregulation of ecto-nucleoside triphosphate diphosphohydrolases 1 and 2 in rat cochlea. Neuroscience 126: 763 773.

Volkov AG, Paula S, Deamer DW. 1997. Two mechanisms of permeation of small neutral molecules and hydrated ions across phospholipid bilayers. Bioelectrochem Bioenerg 42: 153-160.

Wade MH, Trosko JE, Schindler M. 1986. A fluorescence photobleaching assay of gap junction-mediated communication between human cells. Science 232: 525-528.

Wang Y, Chang Q, Tang W, Sun Y, Zhou B, Li H, Lin X. 2009. Targeted connexin26 ablation arrests postnatal development of the organ of Corti. Biochem Biophys Res Commun 385: 33-37.

Wang N, De Bock M, Decrock E, Bol M, Gadicherla A, Vinken M, Rogiers V, Bukauskas FF, Bultynck G, Leybaert L. 2013. Paracrine signaling through plasma membrane hemichannels. Biochim Biophys Acta 1828: 35-50.

Wang HC, Lin CC, Cheung R, Zhang-Hooks Y, Agarwal A, Ellis-Davies G, Rock J, Bergles DE. 2015. Spontaneous activity of cochlear hair cells triggered by fluid secretion mechanism in adjacent support cells. Cell 163: 1348 1359.

Wichmann C, Moser T. 2015. Relating structure and function of inner hair cell ribbon synapses. Cell Tissue Res 361: 95-114.
Willebrords J, Crespo Yanguas S, Maes M, Decrock E, Wang N, Leybaert L, Kwak BR, Green CR, Cogliati B, Vinken M. 2016. Connexins and their channels in inflammation. Crit Rev Biochem Mol Biol 51: 413-439.

Willebrords J, Maes M, Crespo Yanguas S, Vinken M. 2017. Inhibitors of connexin and pannexin channels as potential therapeutics. Pharmacol Therapeut 180: 144-160.

Wu Z, Grillet N, Zhao B, Cunningham C, Harkins-Perry S, Coste B, Ranade S, Zebarjadi N, Beurg M, Fettiplace R, et al. 2017. Mechanosensory hair cells express two molecularly distinct mechanotransduction channels. Nat Neurosci 20: 24-33.

Xia JH, Liu CY, Tang BS, Pan Q, Huang L, Dai HP, Zhang BR, Xie W, Hu DX, Zheng D, et al. 1998. Mutations in the gene encoding gap junction protein $\beta-3$ associated with autosomal dominant hearing impairment. Nat Genet 20: 370-373.

Xu L, Carrer A, Zonta F, Qu Z, Ma P, Li S, Ceriani F, Buratto D, Crispino G, Zorzi V, et al. 2017. Design and characterization of a human monoclonal antibody that modulates mutant connexin 26 hemichannels implicated in deafness and skin disorders. Front Mol Neurosci 10: 298.

Yan D, Zhu Y, Walsh T, Xie D, Yuan H, Sirmaci A, Fujikawa T, Wong AC, Loh TL, Du L, et al. 2013. Mutation of the ATP-gated $\mathrm{P} 2 \mathrm{X}_{2}$ receptor leads to progressive hearing loss and increased susceptibility to noise. Proc Natl Acad Sci 110: 2228-2233.

Ye ZC, Wyeth MS, Baltan-Tekkok S, Ransom BR. 2003. Functional hemichannels in astrocytes: A novel mechanism of glutamate release. J Neurosci 23: 3588-3596.

Yum SW, Zhang J, Valiunas V, Kanaporis G, Brink PR, White TW, Scherer SS. 2007. Human connexin26 and connexin30 form functional heteromeric and heterotypic channels. Am J Physiol Cell Physiol 293: C1032-C1048.

Zelante L, Gasparini P, Estivill X, Melchionda S, D’Agruma L, Govea N, Mila M, Monica MD, Lutfi J, Shohat M, et al. 1997. Connexin 26 mutations associated with the most common form of non-syndromic neurosensory autosomal recessive deafness (DFNB1) in Mediterraneans. Hum Mol Genet 6: 1605-1609.

Zhang Y, Tang W, Ahmad S, Sipp JA, Chen P, Lin X. 2005. Gap junction-mediated intercellular biochemical coupling in cochlear supporting cells is required for normal cochlear functions. Proc Natl Acad Sci 102: 15201-15206.

Zhang X, Zou T, Liu Y, Qi Y. 2006. The gating effect of calmodulin and calcium on the connexin50 hemichannel. Biol Chem 387: 595-601.

Zhang J, Scherer SS, Yum SW. 2011. Dominant Cx26 mutants associated with hearing loss have dominant-negative effects on wild type Cx26. Mol Cell Neurosci 47: 7178.

Zhao HB, Yu N. 2006. Distinct and gradient distributions of connexin 26 and connexin 30 in the cochlear sensory epithelium of guinea pigs. J Comp Neurol 499: 506-518.

Zhao Y, Hu X, Liu Y, Dong S, Wen Z, He W, Zhang S, Huang Q, Shi M. 2017. ROS signaling under metabolic stress: Cross-talk between AMPK and AKT pathway. Mol Cancer 16: 79.

Zhou Y, Yang W, Lurtz MM, Chen Y, Jiang J, Huang Y, Louis CF, Yang JJ. 2009. Calmodulin mediates the $\mathrm{Ca}^{2+}$-depen- 


\section{F. Mammano}

dent regulation of Cx44 gap junctions. Biophys J 96: 2832-2848.

Zhu Y, Liang C, Chen J, Zong L, Chen GD, Zhao HB. 2013. Active cochlear amplification is dependent on supporting cell gap junctions. Nat Commun 4: 1786.

Zimmermann H, Zebisch M, Strater N. 2012. Cellular function and molecular structure of ecto-nucleotidases. Purinergic Signal 8: 437-502.

Zong L, Zhu Y, Liang R, Zhao HB. 2016. Gap junction mediated miRNA intercellular transfer and gene regulation: A novel mechanism for intercellular genetic communication. Sci Rep 6: 19884.

Zonta F, Polles G, Zanotti G, Mammano F. 2012. Permeation pathway of homomeric connexin 26 and connexin 30 channels investigated by molecular dynamics. J Biomol Struct Dyn 29: 985-998.
Zonta F, Polles G, Sanasi MF, Bortolozzi M, Mammano F. 2013. The 3.5 angstrom X-ray structure of the human connexin26 gap junction channel is unlikely that of a fully open channel. Cell Commun Signal 11: 15.

Zonta F, Buratto D, Cassini C, Bortolozzi M, Mammano F. 2014. Molecular dynamics simulations highlight structural and functional alterations in deafness-related M34T mutation of connexin 26. Front Physiol 5: 85.

Zorzi V, Paciello F, Ziraldo G, Peres C, Mazzarda F, Nardin C, Pasquini M, Chiani F, Raspa M, Scavizzi F, et al. 2017. Mouse Panxl is dispensable for hearing acquisition and auditory function. Front Mol Neurosci 10: 379.

Zou C, Wang Y, Shen Z. 2005. 2-NBDG as a fluorescent indicator for direct glucose uptake measurement. J Biochem Biophys Methods 64: 207-215. 


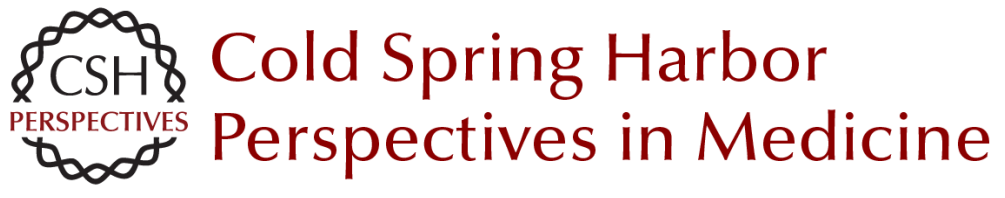

\section{Inner Ear Connexin Channels: Roles in Development and Maintenance of Cochlear Function}

Fabio Mammano

Cold Spring Harb Perspect Med 2019; doi: 10.1101/cshperspect.a033233 originally published online September 4, 2018

Subject Collection Function and Dysfunction of the Cochlea

Hidden Hearing Loss: A Disorder with Multiple

Etiologies and Mechanisms

David C. Kohrman, Guoqiang Wan, Luis Cassinotti, et al.

Hair Cell Afferent Synapses: Function and

Dysfunction

Stuart L. Johnson, Saaid Safieddine, Mirna Mustapha, et al.

Active Biomechanics of Sensory Hair Bundles Dolores Bozovic

The Tectorial Membrane: Mechanical Properties and Functions Jonathan B. Sellon, Roozbeh Ghaffari and Dennis M. Freeman

The Epidemiology of Deafness Abraham M. Sheffield and Richard J.H. Smith

Toward the Optical Cochlear Implant Tobias Dombrowski, Vladan Rankovic and Tobias Moser

Outer Hair Cells and Electromotility Jonathan Ashmore

Interactions between Macrophages and the Sensory Cells of the Inner Ear Mark E. Warchol
Development and Patterning of the Cochlea: From

Convergent Extension to Planar Polarity Mireille Montcouquiol and Matthew W. Kelley

Hair-Bundle Links: Genetics as the Gateway to Function Guy P. Richardson and Christine Petit

Aminoglycoside- and Cisplatin-Induced Ototoxicity: Mechanisms and Otoprotective Strategies

Corné J. Kros and Peter S. Steyger

Function and Dysfunction of TMC Channels in Inner Ear Hair Cells

David P. Corey, Nurunisa Akyuz and Jeffrey R. Holt

Cochlear Gene Therapy

Lawrence Lustig and Omar Akil

Age-Related Hearing Loss

Michael R. Bowl and Sally J. Dawson

Inner Ear Connexin Channels: Roles in Development and Maintenance of Cochlear

Function

Fabio Mammano

A Functional Perspective on the Evolution of the Cochlea Christine Köppl and Geoffrey A. Manley

For additional articles in this collection, see http://perspectivesinmedicine.cshlp.org/cgi/collection/ 